
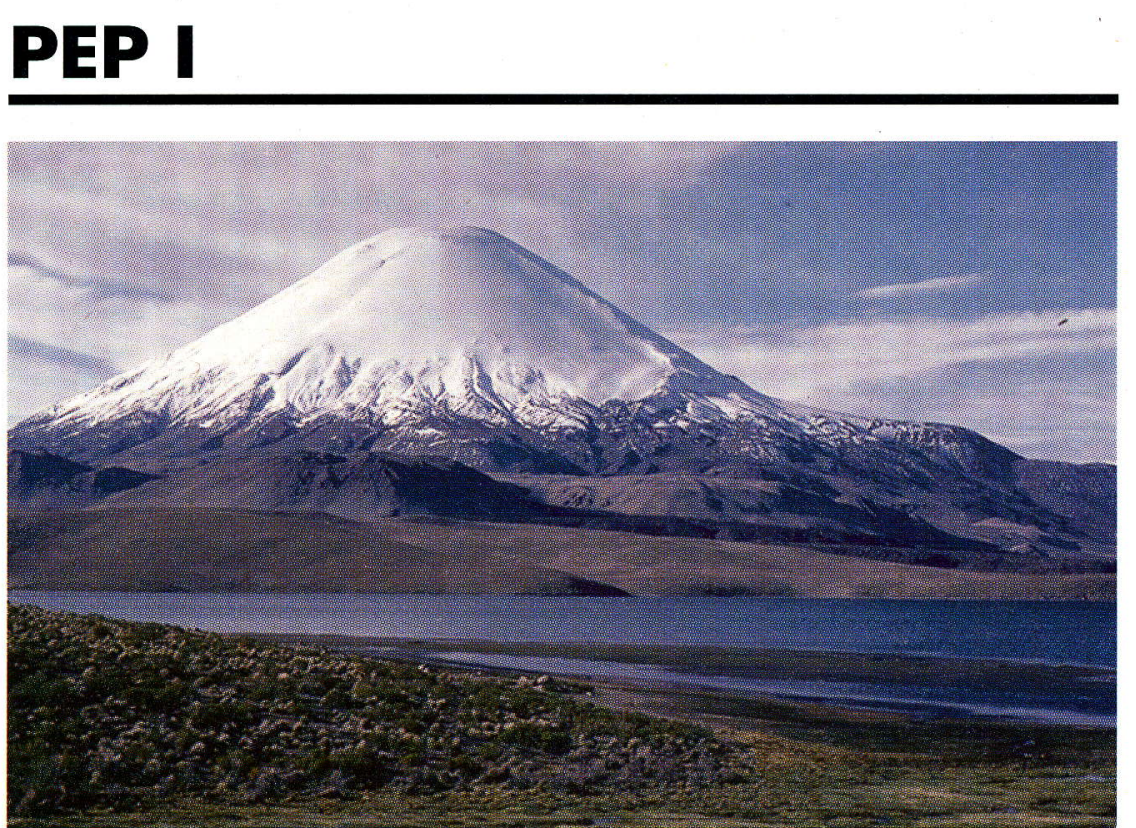

Volcanos, ice cores, lake sediments, peat bogs and treerings: Volcano Parinacota and Laguna Chungara in the Chilean Altiplano are illustrating the variety of paleo-archives available within the PEP I Transect. (Foto: M. Grosjean, Dept. of Geography, University of Bern, Switzerland).

\section{COORDINATION NEWS}

- The plan to convene the first "Interhemispheric Paleoclimates of the Americas" meeting is taking shape.

The meeting will be held in Merida, Venezuela, March 1998.

The following topics, to be organized by coordinators, will be discussed:

- Modern Climate Variability, - El Niño/Southern Oscillation, - Last 2000 Years Climate Variability, - Mid Holocene Climate Optimum/ Neoglacial,

- Late-Glacial Climate Variability, - Last Glacial Maximum.

Coordinators of each topic session will provide a state-of-the-art interhemispheric synopsis, which is followed by specific comparative presentations from the marine and terrestrial realm, addressing interhemispheric linkages.

Presentations will be published subsequently in a book.
- The Spanish translation of the revised and updated PAGES-

PANASH and PEP I portion of the PAGES Series 95-1 is now available

from the coordinator, Vera Markgraf, upon request (PAGES Series 96- 6). Copies were distributed at the II Southern Connection Meeting in Valdivia, January 6 through 11, 1997. This version also includes the revised and updated site inventory of the Latin American Pollen Database, previously published as a Paleoclimatology Publication Series Report No. 4, 1996, (V. Markgraf, L. Anderson, J. Keltner, E. Grimm "The Latin American Pollen Database Site Inventory", World Data Center-A for Paleoclimatology, NOAA Paleoclimatology Program, Boulder, Colorado, 80303). This inventory, which is also available on the WWWeb (http://www.ngdc.noaa.gov/paleo/ paleo/html) lists all reported sites of pollen records in Latin America, including geographic information, radiocarbon chronology, age of record, and publication.

PEP I Research and Workshop Activities

PEP II Activities in New Zealand, China and Taiwan

Workshop Reports

Inside PAGES

National Activities around the World

PAGES Calendar

PAGES Scientific Highlight:

Great Barrier Reef 'Climatic Optimum' at 5,800 Y BP (M. K. Gagan et al.)

EDITORIAL

$T_{\text {his is the first of the new- }}$

style PAGES Newsletters. It

reflects our need to respond to the change in the orientation of PAGES from activities concerned mainly with Agenda-setting, towards an increasing emphasis on the implementation of PAGES research.

In the present Newsletter, we have emphasized in different ways, the activities going on within two of the three PEP (Pole-Equator-Pole) Transects. We have also introduced two examples of developments in PAGES research coordinated at national level, in the hope that this will encourage other national groups and research consortia to submit material for inclusion in future issues.

We plan to circulate three issues of the Newsletter per year, as before and we also plan to retain the main components of previous Newsletters - Workshop Reports, the illustrated, scientific 'PAGES Highlight', short discussion articles, personal news of the PAGES community and the Calendar. The success of all these depends on input from readers as much as on the efforts of the Project Office and editorial staff.

The next newsletter should contain details of developments in PEP III, as well as a major section devoted to the impressive early successes of the IMAGES programme. We shall emphasize short, wellillustrated summaries of 'highlights' wherever possible. The aim is to introduce the strength and flavour of the science in the best and briefest way possible, not to turn the Newsletter into a vehicle for 'grey' publications. 


\section{PAGES - PEP CONTINENTAL DRILLING EFFORTS}

$M$ uch of our present understanding of the long-term behavior of the earth system is based on the great number of long, continuous paleoclimate records from the deep sea and polar ice caps. Comparable long paleoclimate records from the continents, on the other hand, are relatively scarce, despite the fact that they are unique in providing insight into how global and regional climates influence the biosphere upon which humanity is most intimately dependent (see figure of sites with existing and proposed long records along the PEP I transect). To promote and develop a framework for long continental records a PAGES workshop entitled "Continental Drilling for Paleoclimate Records" was convened in Potsdam in 1995, in conjunction with the newly formed International Continental Drilling Program (ICDP). ICDP's goals are to assist in development of major continental scientific drilling projects throughout the world, undertaken to understand, among several other themes, the manner in which Earth's climate has changed in the recent past and the reasons for such changes. The recommendations from this workshop have been published by PAGES (PAGES Series 96- 4).

To help coordinate the fragmented continental paleoclimate community and to further the ICDP-PAGES collaboration, one of the outcomes of the PAGES Continental Drilling Workshop was establishment of a lake drilling task force to develop a prospectus for lake drilling projects linked to the science agenda of the PAGES-PEP transects. Following solicitation of lake drilling planning proposals from the international science community, the task force evaluated and prioritized the proposed projects and submitted a prospectus for a 5-year global lake drilling initiative to the ICDP Steering Committee in April 1996, for

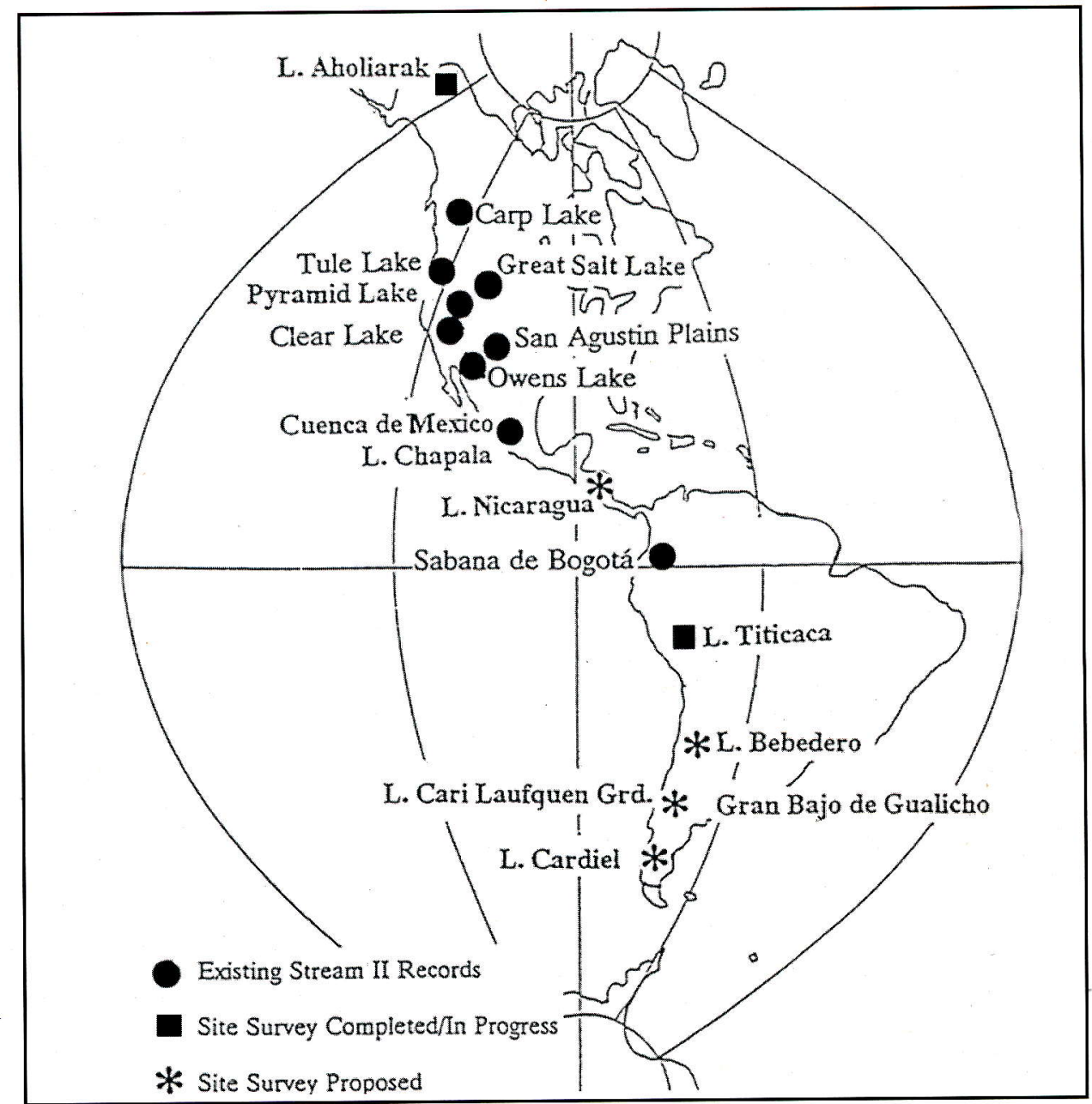

PEP I: lake drilling network

their consideration. At the same time, some projects that were ready to proceed submitted individual pre-proposals to ICDP.

A workshop sponsored by ICDP took place in December, 1996, to facilitate ICDP's consideration of the proposed PAGES-PEP lake drill- ing projects. Because ICDP funds are limited, among other reasons, the PAGES lake drilling plan is meant to be used by the research community to approach all potential funding sources for lake drilling projects, nationally and internationally.

\section{PEP || RESEARCH AND WORKSHOP ACTIVITIES}

With the support of the recently established Inter American Institute for Global Change Research (IAI) several working groups have formed to coordinate interdisciplinary research that addresses the Americas' interhemispheric paleoclimate agenda.

\section{IAI Funded PEP I Related Projects}

- Vegetation History from Fossil Rodent Middens in the Mid- latitude American Deserts (J.L. Betancourt, V. Markgraf, L. Graumlich)

Fossil rodent middens from the deserts in South America (Argentina, Bolivia, Chile, Peru) will be collected and analyzed for comparison with packrat middens from
North American deserts (USA and Mexico) to resolve questions on human impacts on semi-arid rangelands; on how climatic extremes and variability affect long-term vegetation dynamics, biogeography and biodiversity in deserts; and on the interhemispheric interrelation between climate change.

\section{- Ice-core Study on the Environment and Climate of the Antarctic Peninsula and the Southern Part of South America (Laboratorio de Estratigrafía Glaciar y Geoquímica del Agua y de la Nieve (Argentina); Laboratório de Pesquisas Antárticas e Glaciológicas (Brazil); Department of Geography, University of Calgary (Canada); Laboratoire Glacio- logie et Géophysique (France)}

Ice core samples from the Antarctic Peninsula and the Patagonian Icefield will be recovered and analyzed at annual to decadal resolution to identify atmospheric and climatic variability for the last 1000 years. 


\section{IAI Funded Workshops}

\section{- Potential Use of Biological Proxy Data as Climatic Change Impact Indicators in South American Ecosystems (C. Villagrán (Chile), M. Paez, A. Prieto, R. Villalba (Argentina), M.L. Lorscheitter (Brazil)}

During a workshop held in Puerto Alegre, Brazil, in July 1996, members from the paleoclimate community developed a research agenda to evaluate the environmental impacts of future climate change on subtropical ecosystems in Argentina, Brazil and Chile. The proposed approach focuses on analysis of multiproxy paleoclimate records for specific time slices in the past, considered potential analogs for future change.

To enhance the paleoenvironmental response, records will primarily be developed along transects in ecotonal regions;

1) from the Pampas to the Espinal thornscrub, and to the Monte desert:

2) from the Patagonian steppe to the Monte desert, across the Andes, and into the Central Chilean lowlands.

Highest priority in terms of facilitating future collaborative research was considered to be the development of educational and communication aspects. These include development of short courses on different topics in Latin American paleoclimates, such as on climate variability, past, present, and future; the development of paleoenvironmental and paleoclimate bibliographic databases, and of other databases related to the proposed research. (Excerpt from workshop report by C. Villagrán)

\section{- The Assessment of present, Past and Future Climate Variability from Treeline Environments in the Americas (B. Luckman, Canada)}

The western cordillera of the Americas comprise the most complete terrestrial latitudinal transect on earth and flank its largest ocean. These mountains contain several ecotonal environments that have a proven potential to yield high quality multidisciplinary historical and paleo-climate data that can be used to address questions of climate variability at a large range of spatial and temporal scales. To focus on the potential of these ecotones within the context of the PAGES PEP-I transect a workshop entitled "The Assessment of Past, Present and Future Climate Variability in the Americas from Treeline Environments" was held at Jasper in the Canadian Rocky Mountains, October 6th to 10th, 1996. The workshop brought together climatologists, ecologists, paleoecologists, dendroclimatologists, and glacial geologists working in treeline environments in Argentina, Chile, Bolivia, Peru, Central America, Mexico, the US and Canada. The goal of the meeting was to develop an interdisciplinary research agenda to address the response of treeline environments to recent and future natural and human related changes and the implications of these changes for natural resources in mountain environments. The proposed strategy is to establish an interhemispheric network of climate and climate proxy data, from Alaska to Tierra del Fuego, at a nested range of spatial and temporal scales. Such a data set would allow examination of the local and regional patterns of interannual and longer term climate variability and ultimately shed light on the causes of change. Concurrent studies of contemporary environmental responses (e.g. at treeline, snow-line and by glaciers) will be used to benchmark the response of these systems to change. Co-funding for the workshop was received from NSFPEP I, the Canadian government agencies of Atmospheric Environment Service, Environment Canada, Geological Survey of Canada, University of Western Ontario, Jasper National Park, and the Laboratory of Tree Ring Research, University of Arizona.

\section{- Fire and Global Change in Temperate Ecosystems of Western North and South America (T. Veblen, US)}

A workshop funded by a Phase I grant from the Inter-American Institute and held in Oregon in September 1996 under the auspices of AMIGO (America's Interhemispheric GeoBiosphere Organization) brought together scientists from Canada, the US, Argentina and Chile, to discuss a research agenda that would address the role of fire in ecosystem response to global change. The proposed approach focuses on the studey of present and past fire regimes, using dendrochronological and sediment charcoal analysis, across a range of biomes at different spatial and temporal scales in temperate ecosystems of western North and South America. An interhemispheric comparison of fire regimes under different present and past land- use practices, different biotic and abiotic conditions and disturbance regimes, different modes of climate and climate variability, etc., may help disentangle the influences of climate and human activities, a problem of great concern for future land management.

\section{- Comparative Studies on Oceanic and Coastal Processes in Temperate Zones of the Eastern Pacific (T. Baumgartner, USA)}

The workshop was held in Vina del Mar, 11 -16 November 1996, and brought together 52 scientific experts from Chile, Peru, Mexico, the United States and Canada. The purpose was to design a research program which would implement the goals of IAI's Research Theme "Comparative Studies of Oceanic, Coastal and Estuarine Processes in Temperate Zones" for the oceanic and coastal zones of the eastern Pacific, with their distinctive Upwelling and Eastern Boundary Current Ecosystems. The workshop provided the opportunity to create an umbrella strategy to guide development of an overall Science Implementation Plan which included specific Research and Training projects focused on the coastal and oceanic ecosystems extending from the intertidal zone to the pelagic region (0-200 $\mathrm{km}$ offshore). The science agenda and initial implementation plans developed focused on the following topics:

1) Large-Scale Climate (the framework of interannual, interdecadal and centennial climate change),

2) Atmospheric Forcing and Ocean Circulation in the Eastern Boundary Currents,

3) Nutrient and Plankton Dynamics,

4) Near-Shore Ecosystems,

5) Long-term Ecosystem and Climate Histories (Paleo-ecology / Paleo-oceanography/ Paleo-climatology),

6) The Human Dimensions: Socio-Economic Issues and Consequences.

\section{- Workshop on High Resolution Climate Records from High Elevation Ice Cores in the Americas (R. Bradley, D. Hardy, USA)}

To explore the opportunities for research on climate variability in the Americas from high elevation ice cores, a group of 20 scientists representing 11 countries met in San Carlos de Bariloche, Argentina from 11-13 December, 1996. The Workshop focused on the objectives outlined in the PAGES PANASH document (PAGES Report 95-1) for studies along the PEP-I transect.

Discussions focused on regions of the Americas from which additional ice core records could be recovered, and the value of each location in terms of understanding climatic variability. The geographical scope of the workshop discussion extended from the Antarctic Peninsula $\left(\sim 75^{\circ} \mathrm{S}\right)$ to northern Ellesmere Island $\left(83^{\circ} \mathrm{N}\right)$. The meeting was financially supported by the Inter-American Institute for Global Change Research (IAI). The primary goals of the workshop were to identify both the principal scientific questions which can be answered, and societal issues which can be addressed, by ice core studies along a NorthSouth transect through the Americas, to determine which ice caps have the potential of yielding high resolution paleoenvironmental records, and to initiate discussions on programs of collaborative research.

The first session of the workshop was devoted to presentations reviewing the current state of knowledge in three areas:

1) Circulation regimes of South America and meteorological observations at high elevations;

(continued on page 4 bottom) 
This report on PEP II activities uses selected abstracts and presentations from the 1995 Nagoya Symposium to illustrate the strength and diversity of the research being carried out within the vast and complex region spanned by the Transect. A full account of the Meeting and the Abstracts of all the papers can be found in: Mikami, T, Matsumoto, E., Ohta, S. and Sweda T. 'Paleoclimate and Environmental Variability in Austral-Asian Transect during the past 2000 years'. Proceedings of the 1995 Nagoya IGBP-PAGES/PEP-II Symposium, Nagoya. (277pp.).

\section{NEW ZEALAND}

\section{Tree-ring records from subantarctic forests in New Zealand}
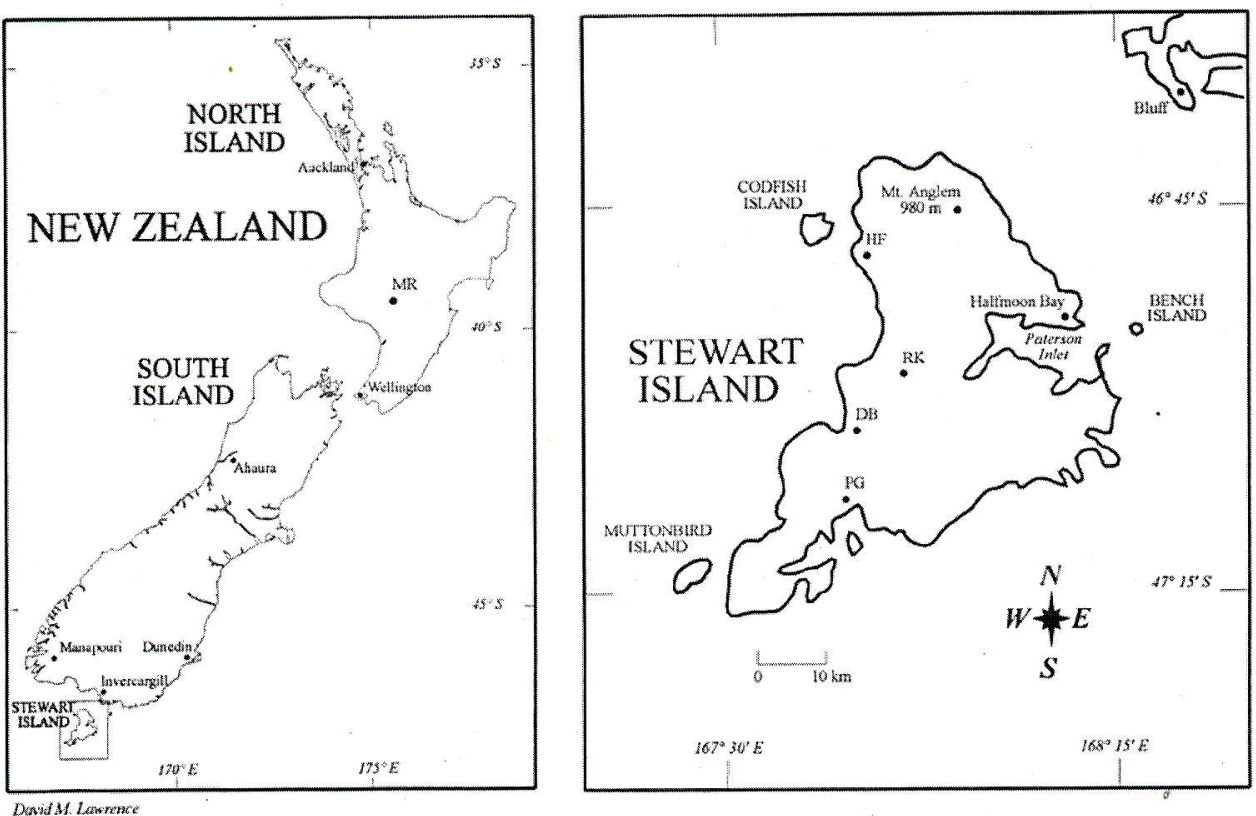

Fig. 1 - Left: Map of New Zealand's North and South Islands and Stewart Island. Manapouri is location of another pink pine site. Ahaura and Mangawhero River Bridge are silver pine sites. Right: Map of Stewart Island and vicinity showing location of pink pine tree-ring sites. DB, Doughboy Bay; RK, Mt. Rakeahua; PG, Pegasusan. Most recent collection (1995) was from Hellfire (HF) site, Ruggedy Mountains, northwestern Stewart Island. (in D'Arrigo, Buckley, Cook, Wagner, "Temperaturesensitive tree-ring width chronologies of pink pine from Stewart Island, New Zealand", in press)
The New Zealand Government has agreed to fund NZ\$300k for drilling of Lake Poukawa on North Island. This is one of the key sites identified as a part of the ICDP.

JoHn DODSON

Temperature-sensitive tree-ring width chro nologies for the Southem Hemisphere include several we have recently produced for pink pine (Halocarpus biformis) from Stewart Island, the southernmost of the three main islands of New Zealand (D'Arrigo et al. $a$ and $b$. in press). These chronologies are positively correlated with warm-season land and marine temperature records for southern New Zealand and vicinity. We have also developed chronologies of silver pine (Lagarostrobus colensoi), closely related to the huon pine ( $L$. franklinii) of Tasmania, for two sites: Ahaura, South Island, and Mangawhero, North Island, New Zealand. Both are updated from series originally published by LaMarche et al. in 1979.

Although there are shorter intervals of comparable warmth, the highest 20-year periods of growth during the past 300 or more years of record for Stewart Island occurred during the middle 1950s-1970s, coinciding with record warming since around 1950 in New Zealand. The updated Ahaura and Mangawhero series also show above-average growth during the recent warm period, with the highest 20-year growth intervals since 1350 occurring in recent decades.

(continued on next page) (continued from page 3 - PEP I)

2) Methodological techniques and issues of ice core analysis;

3) Regionally-specific research accomplishments related to glacier-climate interactions and ice core drilling in the Americas.

Discussions were then conducted on individual regions of the Americas where there are excellent prospects for recovering paleo-environmental records from ice cores. Specific needs and ideas for research projects in each region were identified and plans were laid out for integration of the various projects into a proposal to be submitted to IAI in 1997.

\section{- Large-Scale Biosphere-Atmosphere Experiment in Amazonia (LBA) (C. Nobre et al., Brazil)}

To foster understanding of regional-scale transport in Amazonia, of energy, heat, mois- ture, carbon and other trace constituents, and their interactions and feedbacks, process studies at local to meso-scale are proposed, coordinated under the LBA experiment. To disentangle the role of human impact from natural environmental and climate variability, these experiments include a paleoclimate component, that focuses on identification of the effects the different past precipitation and temperature modes on Amazonian ecosystems. The proposed plan, jointly developed by $\mathrm{B}$. Turq (ORSTOM, Brazil) and P. Colinvaux (Smithsonian, US), calls for development of a network of multiproxy paleoclimate records analyzed with decadal to millenial time resolution. The network of paleoenvironmental records overlaps the network of sites proposed for hydrological, biochemical, and ecological process studies.
- Dendrochronological Studies in Tropical South America with Special Emphasis on Bolivian Forests (J. Boninsegna, R. Villalba, F.A. Roig (Argentina), J. Argollo, S. Beck (Bolivia))

Field reconnaissance, collection and dendrochronologic analysis of different tree taxa from the subtropical and tropical forests in South America should provide information on the potential of tree-ring research for paleoclimate in these poorly known environments.

\section{Submitted by Dr. Vera Markgraf}

Institute of Arctic and Alpine Research University of Colorado

Boulder, Colorado 80309-0450, USA

Phone: 3034925117

Fax: 3034926388

e-mail: markgraf@spot.colorado.edu 
Fig. 2

Top graph: Hellfire, Ruggedy Mt., Stewart Island pink pine chronology. Bottom graph: actual and estimated gridded warm-season temperature and tree-ring data prewhitened to account for effects of autoregression.
Fig. 3

Top graph: update of silver pine chronology for Mangawhero River Bridge, North Island, merged with raw data from chronology (LaMarche et al., 1979). Bottom graph: actual and estimated Auckland warm-season temperatures based on Mangawhero chronology. Temperature and tree-ring data prewhitened to account for effects of autoregression.

Mangawhero ring-width chronology, LaMarche and Tal merged data

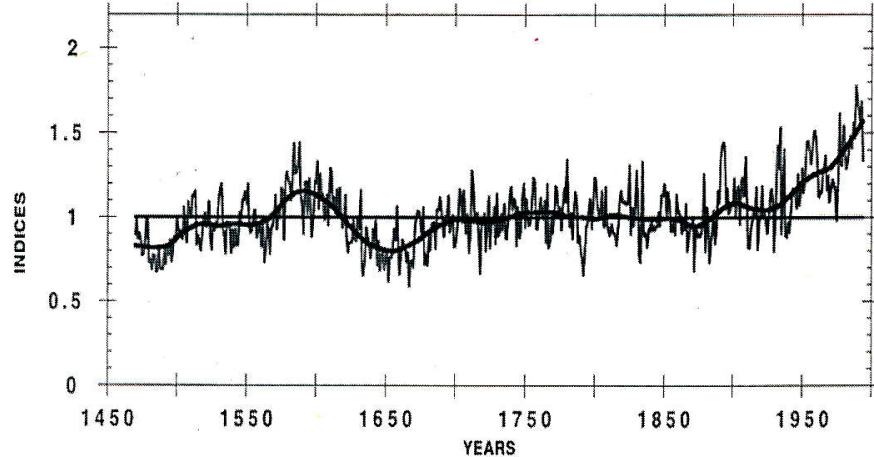

Actual-estimatedwarm season Auckland temperatures

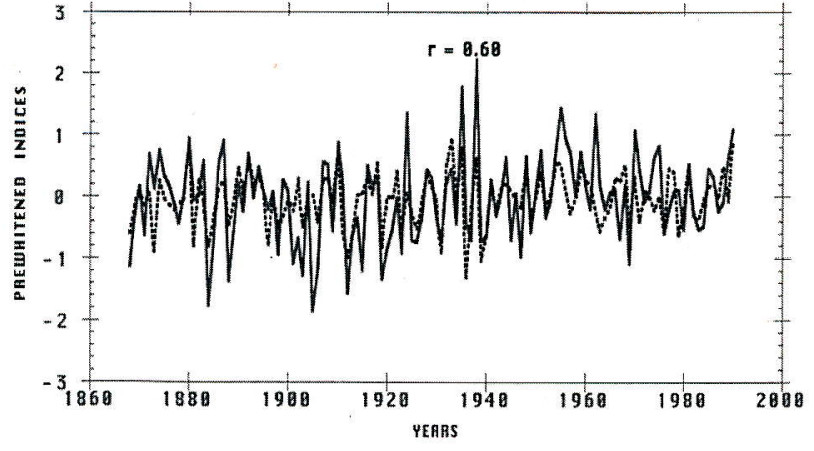

These chronologies supplement previously published tree-ring data from New Zealand (LaMarche et al. 1979, Norton et al . 1989), Tasmania (Cook et al. 1991, 1992, 1994), and southern South America (Lara and
Villalba 1993, Villalba et al., 1994).

Together these tree-ring archives improve our geographical coverage and long-term perspective of climatic variability for data-sparse regions of the Southern Hemisphere.
Rosanne D. D'Arrigo, Edward R. Cook, Brendan

M. Buckley and Paul J. Krusic

Full references can be obtained from the first author at: Tree-Ring Laboratory

Lamont-Doherty Earth Observatory

Palisades, NY-10964, USA

\section{CHINA}

\section{Paleoclimate records available from Chinese historical documents}

Historical documents are a major resource of paleoclimate information in China, They contain the records on drought, floods, rain, snow, freezing, frost, wind, dustfall, atmospheric physical phenomena such as twilight, sky-color, etc., and past records of crops, famine, and insects pests etc.. The earliest one dated from 780 BC.. A systematic study has been conducted on 8128 sources including government history books, local gazetteers, and literature etc.. After detailed proof-reading, cross-checking and establishing the chronology of events, a Chinese historical climate database has been established in the NCC (National Climate Center, China).

A map locating all the sites of records can be obtained from the author.

The records have been employed in recon-
Table 1.

Overall percentages of the paleoclimate records mentioning different items in Chinese historical documents

\begin{tabular}{lcccccccl}
\hline Item & drought & flood & rain & snow & storm & hail & frost & wind \\
Percent $\%$ & 18 & 22 & 9 & 3 & 2 & 5 & 1 & 5 \\
\hline Item & dust & cold & hot & locust & epidemic & famine & harvest & other \\
Percent $\%$ & 2 & 2 & 1 & 6 & 3 & 11 & 7 & 3
\end{tabular}

The table shows some statistics for major items of the database. In addition, ther are the daily weather records extracted from some private diaries, and government weather reports in historical times.

structing regional climatic series mapping the real conditions of extreme climate cases and compiling a chronological table of some rare

\section{Zhang DE'ER}

National Climate Center paleoenvironmental events.

Beiijng 100081, China

\section{References:}

Zhang De'er, 1995, Paleoclimate and Enviromental records available from Chinese historical documents In: Paleoclimate and Environmental Variability in Austral-Asian Transect during the Past 2000 Years.

(eds. T. Mikami, E. Matsumoto, S. Ohta and T. Sweda) Nagoya University, Japan, P.20-26. 


\section{Dust emission from Chinese desert sources linked to large-scale variations in atmospheric circulation}

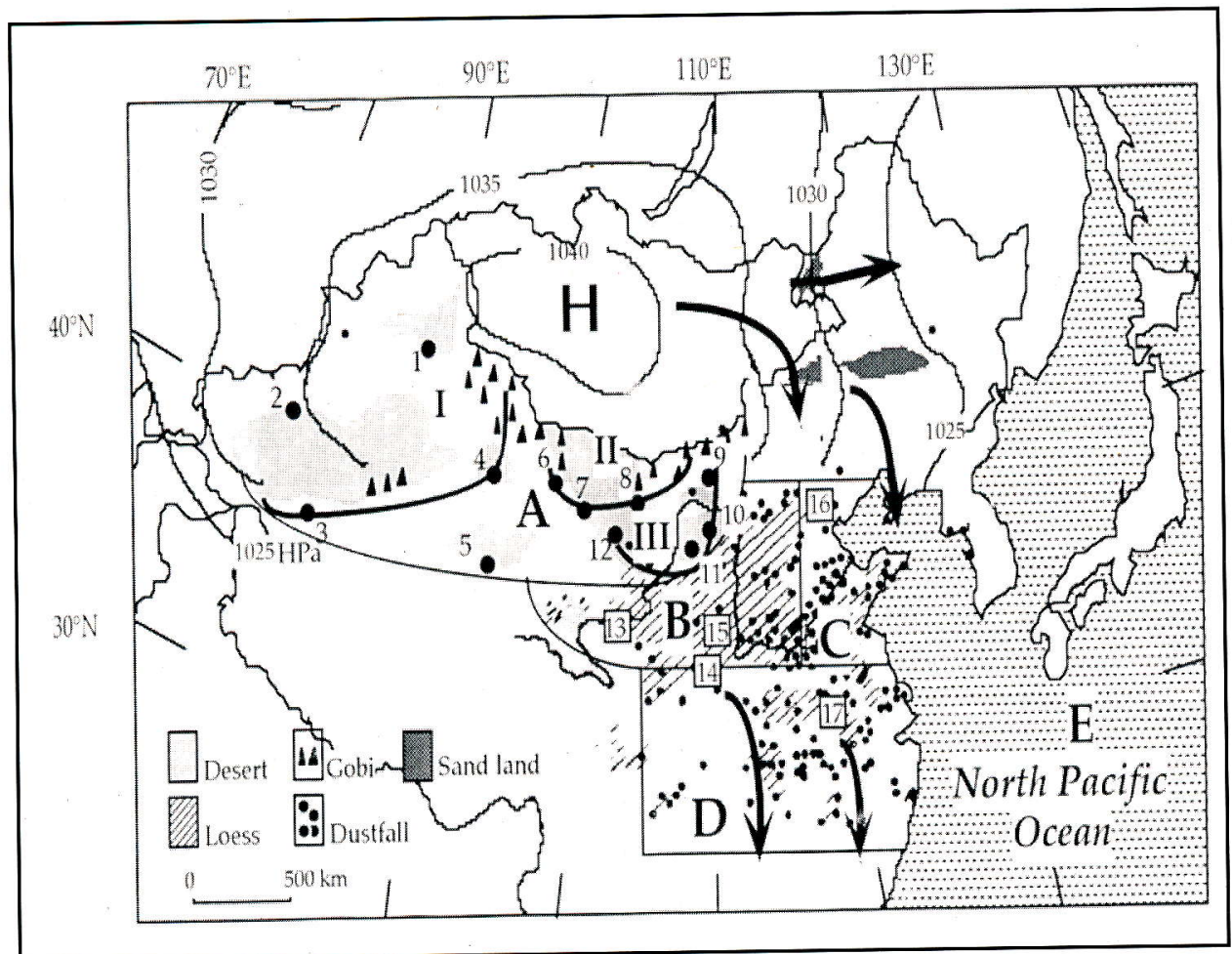

The major sources for Asian dust lie in deserts of northern and northwestern China, but little information is available on the quantity of dust produced or the distribution of source regions. Dust pulses are evident in Chinese loess, but it has not been possible to apportion the contributions among source regions or even pinpoint the source areas. Data from five Asian/Pacific regions indicate that $\sim 800 \mathrm{Tg}$ of Chinese desert dust is injected into the atmosphere annually; about $30 \%$ of this is re-deposited onto the deserts, $20 \%$ is transported over regional-scales, and 50\% is transported to the North Pacificic and beyond. Elemental tracers reveal high-frequency variability in Chinese loess related to dust inputs from western desert sources vs. northern highdust and low-dust desert sources. These shifts in Asian dust source regions are synchronous with large-scale variations in atmospheric circulation over the last glaciation.

Full references are available from the authors who prepared the report.

Xiao Y. Zhang, Zhi S. AN

State Key Laboratory of Loess and

Quaternary Geology

Academia Sinica, P.O.Box 17

$X^{\prime}$ an 710054 , China

\section{Richard Arimoto}

Center for Atmospheric Chemistry Studies,

Graduate School of Oceanography

University of Rhode Island

Narragansett, RI 02882-1197, USA.
The map shows the winter monsoon regimes of eastern Asia, aerosol sampling locations (1-12) in Chinese deserts, the sites (open squares with numbers) for the data cited, source regions (Sources $I, I I, I I)$ and depositional regions (Regions $A, B, C$,

\section{CHINA}

Stalagmites are a kind of speleothem able to provide climate information with an annual resolution and much longer time span comparing to tree rings. Two aspects of annual banding of stalagmite have been reported: the luminescent microbanding which is only observed under a fluoromicroscope (Y. Shopov 1987, 1994 and A. Baker 1993) and the lamina which are visible to the naked eye (D. Genty 1996). Recently, the authors have studied a stalagmite from Beijing Shihua Cave within the East Asian monsoon zone and found under the polarizing microscope the transparent micro-banding is very clear. The preliminary results show that about 1100 continuously microbands are in the upper $45 \mathrm{~mm}$ of the stalagmite (Fig. l).

Each band, taken as annual deposition, mostly tens of microns in thickness, consists of two parts:

- a light part at its bottom which may be deposed from the "old water" in the fissures displaced by annual rainfall,
1. Fukang $\left(44^{\circ} 17^{\prime} \mathrm{N}, 88^{\circ} 7^{\prime} \mathrm{E}\right), 2$. Aksu $\left(41^{\circ} 22^{\prime} \mathrm{N}\right.$, $\left.80^{\circ} 43^{\prime} \mathrm{E}\right)$, 3. Qira $\left(37^{\circ} 6^{\prime} \mathrm{N}, 82^{\circ} 34^{\prime} \mathrm{E}\right), 4$. Dunhuang (40 $\left.16^{\prime} \mathrm{N}, 94^{\circ} 10^{\prime} \mathrm{E}\right), 5$. Golmud ( $\left.36^{\circ} 62^{\prime} \mathrm{N}, 96^{\circ} 64^{\prime} \mathrm{E}\right)$, 6. Jiayuguan $\left(40^{\circ} 38^{\prime} \mathrm{N}, 98^{\circ} 31^{\prime} \mathrm{E}\right), 7$. Heiquan $\left(40^{\circ} 26^{\prime} N\right.$, $\left.100^{\circ} 16^{\prime} E\right)$, 6.jiayuguan $\left(40^{\circ} 38^{\prime} N\right.$, 98 $31^{\prime} \mathrm{E}, 8$. Jartai $\left(40^{\circ} 34^{\prime} \mathrm{N}, 106^{\circ} 34^{\prime} \mathrm{E}\right)$, 9. Dalad Qi $\left(40^{\circ} 63^{\prime} \mathrm{N}, 110^{\circ} 6^{\prime} \mathrm{E}\right), 10$. Yulin $\left(38^{\circ} 37^{\prime} \mathrm{N}, 109^{\circ} 46^{\prime} \mathrm{E}\right)$, 11. Dingbian $\left(37^{\circ} 37^{\prime} N, 107^{\circ} 34^{\prime} E\right)$, 12. Minqin (3997'N, 103 10'E), 13. Lanzhou, 14. Xian, 16. Luochuan, 16. Beijing, 17. Hefei.

\section{Source Regions:}

I-Western deserts $(2,3,4)$; II-Northern high-dust deserts $(6,7,8)$; III-Northern low-dust deserts (9-12).

\section{Depositional Regions:}

A: Chinese desert regions (1-12), excluding three sandy lands in northeastern China;

B: Chinese Loess Plateau $(13,14)$,

C: Historical NE dustfall region, $34.3-41^{\circ} \mathrm{N}$, to the east of $114^{\circ} \mathrm{E}$ (16);

$D$ : Historical SE dustfall region, $27.3-34.3^{\circ} \mathrm{N}$, to the east of $104.7^{\circ} \mathrm{E}(17)$; E: North Pacific Ocean

$D, E)$ for Asian dust. The prevailing northwesterly winds (arrows) associated with the Siberian High $(\mathrm{HPa})$ and westerly winds from central Asia entrain the bulk of the Chinese desert dust delivered to the depositional areas.

\section{Microbanding of stalagmite and its significance}

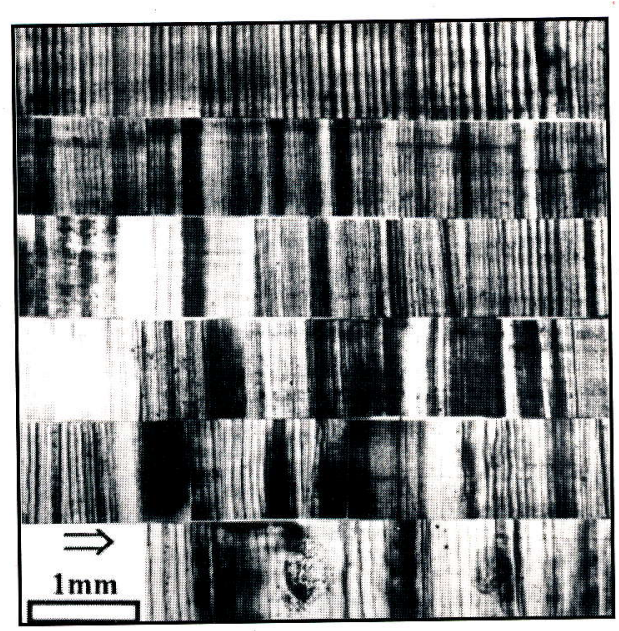

Fig. 1:

The 1100 annual transparent microbands of the stalagmite from Beijing Shihua Cave. The order from the top to the bottom and from the left to the right in the figure is in the direction from the top to the base in the stalagmite. The scale is I $\mathrm{mm}$ illustrating the size of the banding. The round dots in the first row of photograph are pen-marks. 
- a dark one on the top which may be deposited from "fresh water" which comes from the overlying soil and contains more organic matter.

The cave was developed in Ordovician limestone. The stalagmite which is about $200 \mathrm{~mm}$ high and columnar in shape, was taking in the drip water when it was cut. The AMS ${ }^{14} \mathrm{C}$ dating suggests that the stalagmite has an age less than 2000 years. It seems reasonable to suppose that the rythmic banding is comparable to the fluctuations in the annual precipitation which has only one annual peak value in most years in the monsoon zone and undergoes interannual changes in a wide range similar to the bands. Assuming this interpretation correct, the authors have developed the time series of band thickness and compared them with the index of drought and flood drawn from historical documents of the last 500 years (from 1470 to $1992 \mathrm{yr}$ AD, Fig. 2a) and the instrumental record of precipitation from 1951 to $1980 \mathrm{yr}$ $\mathrm{AD}$ (according to the data from National Climate Center, Fig. 2b). The coherence of these curves suggest once again that the banding has an annual resolution. Consequently, the light and dark parts for each band may reflect seasonal hydrological changes. With the curve of thickness change the authors reconstruct an annual resolution climatic history of the last 1100 years in the Beijing area (Fig. 2c). The precipitation was at its height in about $900 \mathrm{yr}$ BP and after that time it was decreasing to the lowest in about $515 \mathrm{yr}$ BP (start from $1980 \mathrm{yr}$ $\mathrm{AD})$, then gradually increasing up to its 20th century maximum in the 1950's. 136-year, 50year, 18 16-year, 11-year and 5.8-year climatic cycles are observed.

Full references are available from the authors.

Tan Ming, Liu Tungsheng, Qin Xiaoguang,

Institute of Geology, Chinese Academy of Sciences, Beijing 10029, China

\section{Zhang De'ER}

National Climate Center

Beijing 100081, China

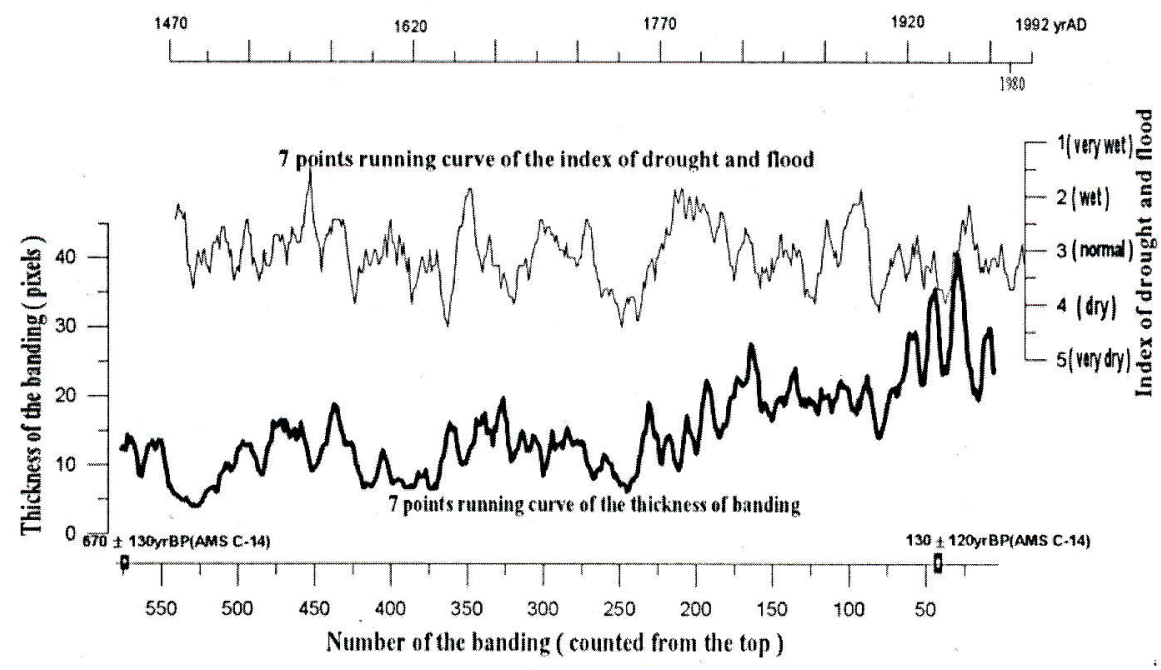

b
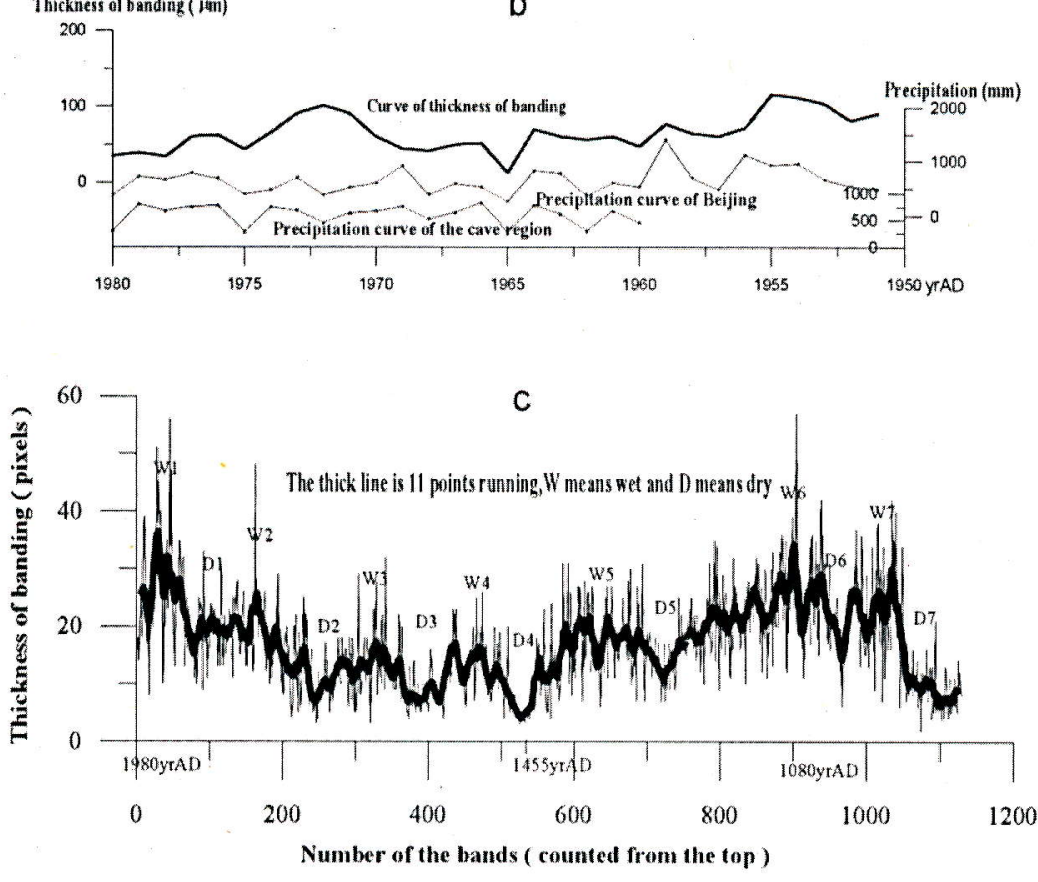

Fig. 2:

2a: Comparison between the variation of banding thickness and the index of drought and flood recovered from historical documents over the last 500 years.

$2 b$ : Comparing the change of banding thickness with the instrumental records of precipitation from 1951 to 1980 yr $A D$.

$2 c$ : The variation of the banding thickness in the last 1100 years, which may represent the change in precipitation.

A Chinese version of the PANASH-PEPII report has been produced and is available from

Guo Zhentang at:

Institute of Geology, Chinese Academy of Sciences, P.O. Box 9825, Beiiing 100029, CHINA

phone: +86 10/6202776 ext.345/330, fax: $+8610 / 62052184$ or 64919140 ,

e-mail: ztguo@mimi.cnc.ac.cn

A French version of the PANASH-PEP III report is in preparation.

Further details will be given in our next PAGES Newsletter. 


\section{Coral $\mathrm{Sr} / \mathrm{Ca}$ as a High Precision High Time-Resolution Paleo-Thermometer for Sea Surface Temperature: Looking for ENSO Effects in Kuroshio near Taiwan}

Applying the newly developed coral Sr/ Ca paleo-thermometry to core samples from southern Taiwan, we have detected a $1-2^{\circ} \mathrm{C}$ warming in the sea surface temperature (SST) for the winter of 1982-83. Our tentative interpretation is that the strong ENSO of 1982-83 caused the warming through an enhanced Kuroshio Current or a reduced northeast winter monsooon. However, detailed comparison between the proxy SST record from coral and the SST in the Comprehensive Ocean-Atmosphere Data Set (COADS) revealed several discrepancies of similar size implying that further study is required to establish such a possible teleconnection.

Typhoon Lee', Chuan-Chou Shen', Chung-Ho Wang ${ }^{\prime}$ Chin-Hsin Chiu ${ }^{2}$, Chang-Feng Dal ${ }^{2}$, Ju-Chin Chen ${ }^{2}$

1: Institute of Earth Sciences

2: Institute of Oceanography,

National Taiwan University

Full references can be obtained from Typhoon Lee at: Institute of Earth Sciences

Academia Sinica

P.O.Box 1-55, Nankang

Taipei, TAIWAN 115 R.O.C.

e-mail: typhoon@biaa3.biaa.sinica.edu.tw

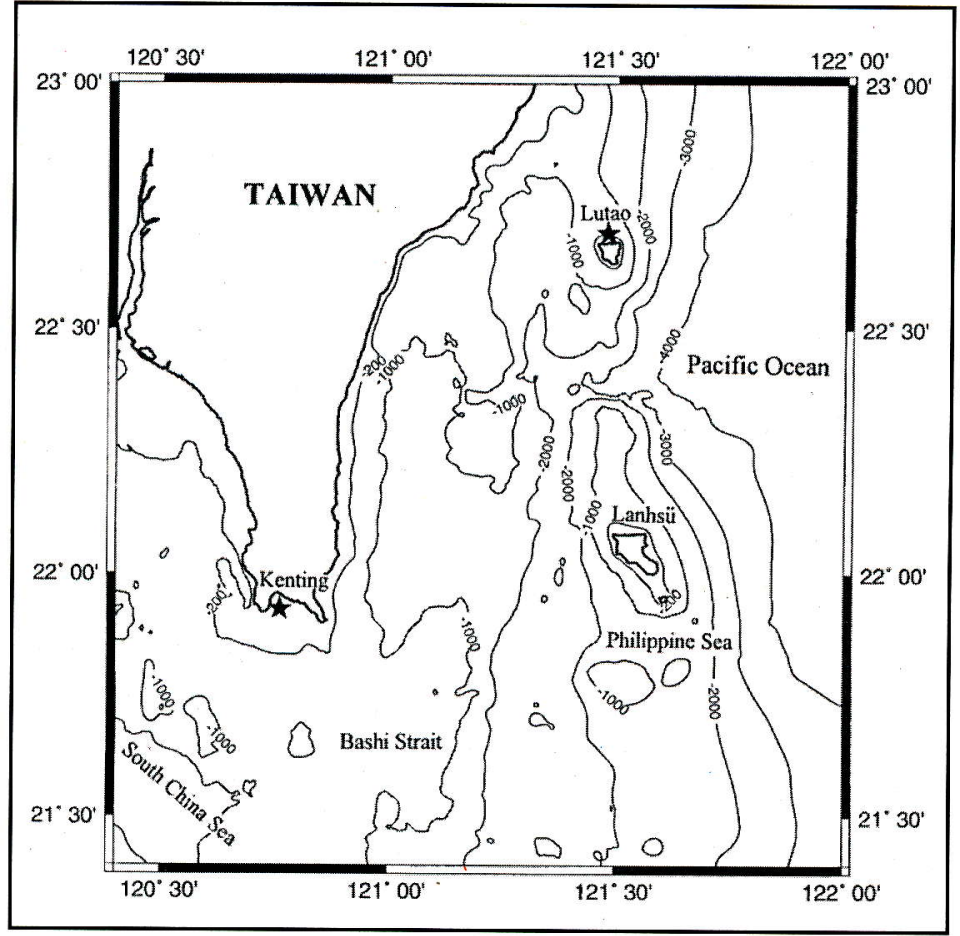

Our coral samples were drill cores from large Porites heads in Kenting and Lutao. These corals have been growing continuously from about 200 years ago. Kenting is where we calibrated the $\mathrm{Sr} / \mathrm{Ca}$ vs. Sea Surface Temperature (SST) relationship. It faces the Bashi strait which is the only deep opening of the South China Sea to the Pacific. Lutao is in the Kuroshio Current and our sampling site there (marked by star) is directly exposed to the winter monsoon from the north east.

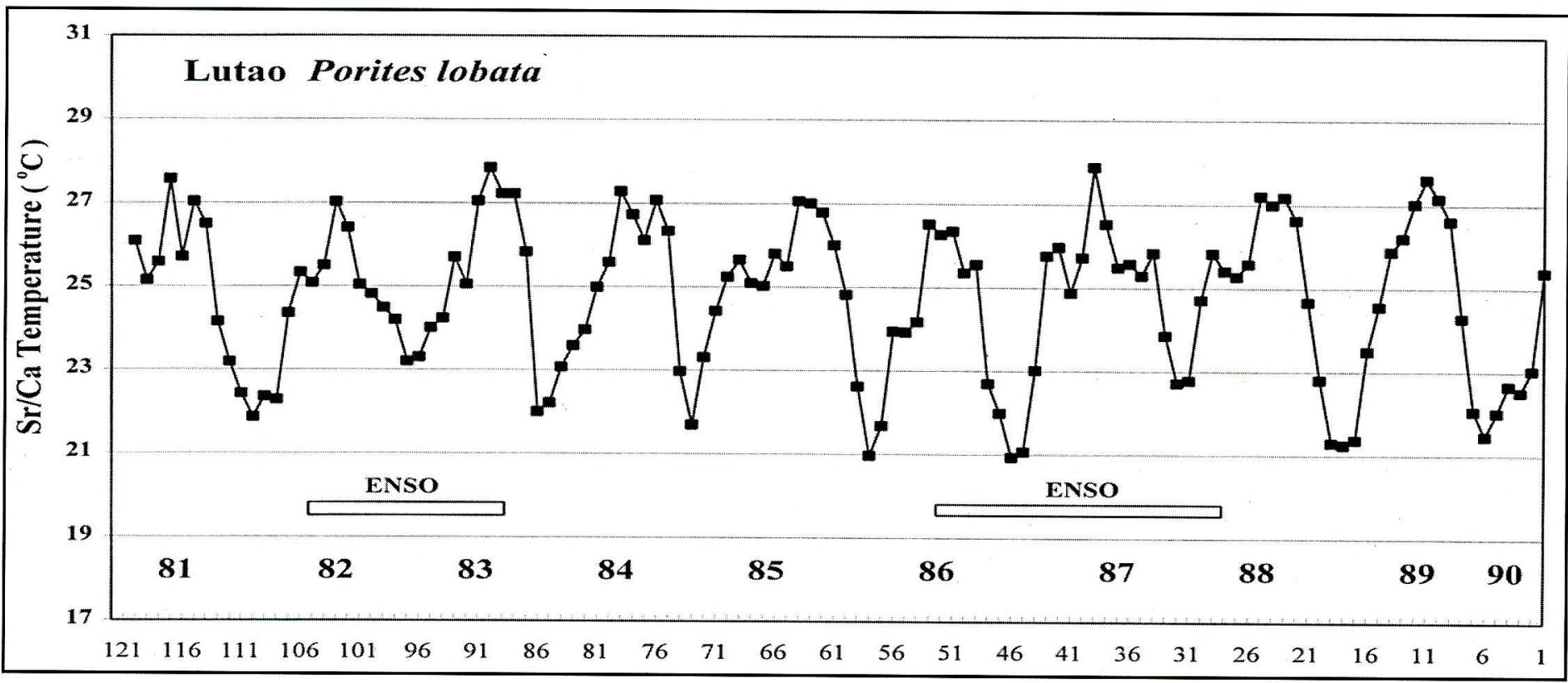

The 1981-90 SST inferred from Sr/Ca of Lutao coral assuming Lutao seawater has the same Sr/Ca as Kenting, the calibration site. The winter SST was warmer than usual by $1-2^{\circ} \mathrm{C}$ for $1982-83$ and $1987-88$, both of which coincide with ENSO events. Note that the absolute SST scale for Lutao is still uncertain because the measurement of Lutao seawater Sr/Ca is still in progress and we have assumed there that it is the same as Kenting (probably not quite correct). However, a change in seawater Sr/Ca does not affect the relative difference between SST of one winter to that of other winters for the same site. We suspect that this warming was the result of the decrease in cooling caused by a particularly weak NE monsoon since the analysis of COADS wind data revealed an unusually weak NE monsoon for the winter of 1982-83 (Chao et al. 1996, Prog. Oceanography, submitted). 


\section{1st PAGES/CLIVAR Working Group Meeting}

IGBP-PAGES and WCRP-CLIVAR recently teamed up to establish the PAGES/CLIVAR Working Group (WG). The impetus for this new WG stems directly from the November 1994 joint IGBP-WCRP workshop (Venice, Italy) on climate variability and predictability, and from the recognition that the new WCRP CLIVAR program needs a firm paleoenvironmental perspective to meet its needs. With the establishment of the PAGES/CLIVAR WG, PAGES (Past Global Changes) becomes one of the first IGBP (International Geosphere-Biosphere Programme) core project to also serve the WCRP (World Climate Research Programme).

$T^{\text {he }}$ he first meeting of the PAGES/CLIVAR WG was just held (October 24-25) in Villefranche-sur-mer, France, and included participants from both the PAGES and CLIVAR research communities.

Building on the recently published 'PAGESCLIVAR Intersection' document (edited by J. C. Duplessy and J. Overpeck, and available from either PAGES, CLIVAR or the Internet WWWeb at http://www.ngdc.noaa.gov/ paleo/reports/clivar.htm), the WG agenda called for a critical review of what paleoclimatic data and methods are available for addressing CLIVAR seasonal- to centennial-scale climate variability issues. This led to discussions focused on specific areas of potential CLIVAR-PAGES interaction, and then to ways to improve the interdisciplinary interaction between the PAGES and CLIVAR communities.

A full report on the WG presentations and recommendations will be published as a joint CLIVAR/PAGES document. The recommendations are summarized here.

As a general preamble, it was decided that PAGES/CLIVAR interactions focus on:

- societially-relevant climate variability (e.g., droughts, floods, storms) and the processes driving this variability, with the recognition that extremes of the 20th century were small relative to those of the preceding centuries and millennia;

- understanding seasonal to century-scale variability as a prerequisite to reliable predictive capability, with the acknowledgment from the paleoclimatic record that decadal to century-scale variability modulates seasonal to interannual variability, and that climate states can abruptly change and persist for decades or longer;

- unraveling key phenomena and mechanisms of climate variability;

- understanding tropical-extratropical interactions.

The intersection of CLIVAR foci and PAGES capabilities led to the identification of several key phenomena and mechanisms for joint study. Each of these phenomena exhibits behavior that can be investigated only with the aid of a paleoclimatic perspective, and only the paleo-record contains empirical information on how these phenomena are affected by changes in climatic forcing. Among these phenomena are specifically:

- ENSO atmosphere-ocean interactions and extratropical linkages;

- Tropical/North Atlantic variability, and interactions between tropical processes and regional drought, the North Atlantic Oscillation, and thermohaline circulation;

- Asian/African monsoon dynamics, linkages with ENSO and extratropical variability;

- shallow meridional ocean circulation and other processes as a mechanisms that link tropical and extratropical climate variability.

It was concluded that many paleoenvironmental tools are available for improving our understanding of these phenomena, with particular interest in insights that can be obtained from coral, ice core, sediments, historical and tree-ring data. These proxies, in conjunction with modeling studies and interdisciplinary interaction between the CLIVAR and PAGES communities, will provide a powerful basis for attacking several specific CLIVAR-relevant objectives. It is recommended that the above-mentioned phenomena and mechanisms be examined with a view to the following specific actions:

\section{Recommended Action 1: a detailed study of climatic variability}

A detailed study of the climatic variability of the last 400 years (globally) and the last 1000 years (where possible). The goal here is to provide the first comprehensive understanding of natural (non-anthropogenically-forced) seasonal to interdecadal variability, and to put the last 100 years in the context of the last 1000. Where possible, the emphasis will be on deriving and using global fields of multiple climatic parameters (e.g., temperature, precipitation, seá-ice), and on the combined use of reconstructed time series of both climate observations and climatic forcing (e.g., SST; volcanic optical depth, solar, trace-gas, and aerosols).
Recommended Action 2:

a comprehensive study of climatic variability

A comprehensive study of climate variability given climatic states and forcing that are significantly different from today. The primary objective acknowledges the fact that global climatic forcing is changing dramatically, and that this means that future climatic variability could be distinctly different from any of the last 150 years. The paleoclimatic record suggests that each of the above-mentioned key phenomena may have been significantly different during the mid-Holocene and Last Glacial Maximum. Thus, specific attention should be given to reconstructing, understanding and modeling climate variability of 6,000 and 21,000 years before present.

\section{Recommended Action 3: a detailed investigation of transient climatic events}

A detailed investigation of major abrupt transient climatic events of the Holocene and Pleistocene. The focus here is on climatic events of the past that, if they were to occur today, would have profound impact on human societies. Past abrupt changes occurred on seasonal to decadal time scales, and provide key insights into how the coupled climate system may respond to altered climate forcing in the future. This recommended PAGES/ CLIVAR action is aimed at avoiding devastating climatic "surprises" in the future, and should be aimed ultimately at developing a predictive ability to simulate major abrupt changes in climatic variability.

The WG discussed linkages to other projects. Most relevant were the PAGES/ CLIVAR ARTS (Annual Records of Tropical Systems) Initiative, and the Paleoclimate Modeling Intercomparison Project (PMIP), both of which focus on meeting the specific PAGES/ CLIVAR priorities listed above. A number of additional PAGES activities and tasks are also of great relevance to PAGES/CLIVAR. Increased coordination with these efforts will be a goal of PAGES/CLIVAR.

The WG meeting ended with a discussion of how interaction between the PAGES and CLIVAR communities could be improved. It is recommended that both focused interdisciplinary science meetings and cross-disciplinary short-courses be held at regular intervals in the future. In many cases, the science meetings should be collaborative with existing PAGES and CLIVAR efforts. Improved interdisciplinary data sharing should also be built upon the existing PAGES data management program at the World Data Center-A for Paleoclimatology, 
with a special PAGES/CLIVAR Internet (WWW) interface for data and information sharing. Lastly, the PAGES/CLIVAR WG calls for greater participation of paleoclimatologists in other CLIVAR activities (i.e., those associated with GOALS, DecCen and ACC).

This summary was provided by PAGES/ CLIVAR WG Co-chairs J-C. Duplessy and J. Overpeck. Additional information, including a list of WG members, can be obtained by con- tacting either PAGES or CLIVAR. A full report of the WG meeting will soon be published (in hard and electronic forms) jointly by PAGES and CLIVAR.

\section{Dr. Jonathan T. Overpeck}

NOAA Paleoclimatology Program

National Geophysical Data Center

325 Broadway E/GC

Boulder, CO 80303 , USA

Phone: 303-497-6172

Fax: 303-497-6513

e-mail: jło@ngdc.noaa.gov

\section{New members at the PAGES Scientific Steering Committee}

The PAGES Scientific Steering Committee welcomed three new members at the start of 1997.

\section{Arrivals...}

Dr Patrick De Deckker, who was born in Belgium, is Reader in the Department of Geology, The Australian National University. He has published widely in taxonomy, ecology, paleoecology, water chemistry, geochemistry, paleolimnology, paleoceanography, paleoclimates, limnology and archaeology.

Dr G.B. Pant is Deputy Director of the Indian Institute of Tropical Meteorology and Head of the Climatology and Hydrometeorology Division. His main academic interests lie within the fields of Atmospheric energetics, Climate and climate change, Paleoclimatology and Climate Modeling.

Dr Dominique Raynaud is Research Director of the CNRS 'Laboratoire de Glaciologie et Géophysique de l'Environment' in the University of Grenoble. He has participated in several, mainly Antarctic, Polar expeditions and published widely on ice core research, the carbon cycle and paleoclimate. He also serves PAGES as the leader of the Antarctic PICE programme.

\section{... and departures}

The pleasure of welcoming new members to the PAGES SSC is always mixed with regret for departing members.

At the end of 1996, Claude Lorius, Eric Odada and Bob Wasson ended their period of service. All made outstanding contributions to the work of PAGES, Claude especially in the area of Antarctic Ice Core-based research for which he has been honoured internationally at the highest level, Eric for his major contribution to PAGES Science in Africa not only through his work with IDEAL, but also through his wide knowledge and contacts, Bob for his commitment both to southern hemisphere matters and to the theme of human impact within the overall framework of Global Change.

stantial contributions to the awarness of global change. Established in 1991, the Revelle Medal recognizes oustanding accomplishments or contributions towards the understanding of the Earth's atmospheric processes including its dynamics, chemistry, and radiation; and towards the role of the atmosphere, atmosphere-ocean coupling, or atmosphere-land coupling in determining the climate, biogeochemical cycles, or other key elements of the climate system.

Edward N. Lorenz was the first recipient of this medal, given not more often than annually. The previous recipients were Edward N. Lorenz (1992), Syukuro Manabe (1993), F. Sherwood Rowland (1994), Wallace S. Broceker (1995), Robert E. Dickinson (1996)

Cindy Jones, who, along with Ulrich Schotterer, takes the credit for the extremely attractive and professional format of our 1995 publications, is now a member of the PAGES staff. Her first task, as Publications Officer has been to produce this Newsletter. 
CANADA

\section{Water and Climate Studies in Canada using Isotope Tracers: Past, Present, Fułure}

31 st January and 1st February 1997,

Waterloo, Canada

Report of the workshop

This two-day workshop was convened with the twin aims of reviewing the state of water and climate research in Canada using isotope tracers and investigating the establishment of a revitalized "Canadian Network for Isotopes in Precipitation", as a contribution to the international GNIP program (Global Network for Isotopes in Precipitation), which is the well-known offspring of long-standing IAEA/WMO efforts to document the distribution of water isotopes in the global water cycle. About 60 participants from university, government, and the private sector gathered for two days of presentations and discussions at the University of Waterloo, Ontario, Canada.

The workshop was sponsored by Environment Canada, through the Atmospheric Environment Service (Downsview, Ontario) and the National Hydrology Research Institute (Saskatoon, Saskatchewan), with additional support from the Canadian Geophysical Union, the Waterloo Centre for Groundwater Research, and several other Waterloo-based university research bodies.

Background on international GNIP activities, the PAGES perspective, and comments on experience gained from national isotope networks in Switzerland and Germany were provided in Plenary Lectures from, Klaus Froehlich (IAEA) and Ulrich Schotterer (PAGES). Special guests Emi Ito (University of Minnesota) and Carol Kendall (US Geological Survey) offered narrative on the current situation in USA regarding potential for developing a national precipitation network and the existing USGS isotopic data base from surface waters. Subsequent presentations were selected to sample the broad spectrum of past and present activities in Canada, falling into three general areas: assessment of existing isotopic data from past and ongoing precipitation sampling in Canada and efforts to define the nature of isotope-climate linkages; atmospheric studies, including discussion of carbon and oxygen stable-isotope signals in atmospheric carbon dioxide and links with the water cycle; and the use of isotope tracers in hydrologic, paleohydrologic, and ecologic studies of surface and ground waters, groundice, and the water isotope records preserved in other archives.

The presentations demonstrated clearly that substantial Canadian expertise exists in this field, complemented by the capacity and willingness to train young researchers. The discussions also led to consensus that an ex- panded network of 20-30 meteorological stations collecting monthly-composite precipitation samples for isotopic analysis was desirable and feasible, building on the network of sites in Canada currently contributing data to GNIP. The existing "CNIP" includes Ottawa (1953-present) and eight northern stations (1989-present), plus data in the GNIP archive from previous monthly-composite sampling campaigns at a number of other sites in the 1970 s and 1980s. Various targeted research projects, including ongoing event-based precipitation sampling in Winnipeg (1992present), have also generated abundant data that are not yet formally archived. A revitalized CNIP would constitute a valuable Canadian contribution to international water and climate studies, as well as providing a framework for nested campaigns requiring more intensive temporal or spatial sampling, such as the Mackenzie Basin Study of the Global Energy and Water Cycle Experiment (GEWEX-MAGS).

The workshop culminated in a provisional agreement to work towards the establishment of a rejuvenated and expanded CNIP, based on a model in which responsibilities for sample collection and analysis would lie, respectively, with the Atmospheric Environment Service of Environment Canada and a consortium of university and government isotope laboratories. A special sub-committee of the Committee on Isotope Tracer Techniques within the Hydrology Section of the Canadian Geophysical Union will assume responsibility for overall scientific direction and administration, and the continuity of the program.

Aspects of the challenges and opportunities associated with CNIP will also be addressed at the upcoming annual meeting of the Canadian Geophysical Union (Banff, 4-9 May 1997) and the ISOBALANCE International Workshop on Application of Stable Isotopes in Water Balance Studies (Saskatoon, 1418 July 1997).

Further information about the CNIP Workshop and ongoing activities can be obtained through:

\section{Thomas W.D. EdWARds}

Associate Professor Dept of Earth Sciences

University of Waterloo

200, University Avenue West

Waterloo, ON N2L 3G1, CANADA

Phone: + 15198884567 ext 3236

Fax: +15197460183

e-mail: twdedwar@uwaterloo.ca
GERMANY

Cooperative Research

Project "ACACIA"

(Arid Climate, Adaptation and Cultural Innovation in Africa) 1995-2010

This long term research initiative in Germany contains several sub-projects of interest to PAGES. Three of these are described briefly below.

Further information can be obtained from the project leaders through Stefan Kroepelin.

\section{CLIMATIC CHANGE AND HUMAN SETTLEMENT BETWEEN THE NILE VALLEY AND THE CENTRAL SAHARA}

In follow-up to the long-term interdisciplinary project, "B.O.S." (Settlement History of the Eastern Sahara; 1980-1995) further and more detailed research will be conducted in the Northern Libyan Desert. This sub-project focuses on the initial stages and spread of food-producing economies, the general question regarding the mono- or polycentric development of Neolithic phenomena, and the relevance of these processes to the birth and rise of Egyptian civilization.

Since the ecological setting for human activity in this region can be divided into three larger environmental zones - the summer rains in the North, winter rains in the South, and the Nile Valley in the East - the study of regional climatic development is a necessary prerequisite for understanding the historical development and the possible role and range of interregional contacts. Therefore, a detailed regional chronology must be determined based on geomorphological / sedimentological analyses as well as archaeological excavations, which take into consideration palaeobotanical and archaeo-zoological aspects.

Within the general framework of the Cooperative Research Project - man and his environment - this sub-project focuses on the earliest indications of the interdependence between socioeconomic development and environmental conditions, investigates the transition to a productive economy, and therefore endeavours to record the initial stages of cultural change, which apparently began in the north of the continent and following a few millennia would later affect the south. 


\section{WADI HOWAR - SETTLEMENT AREA AND THOROUGHFARE AT THE SOUTHERN MARGINS OF THE LIBYAN DESERT}

Located on the southern fringes of the Libyan Desert, the Wadi Howar is the largest dry river system in the Eastern Sahara stretching over $800 \mathrm{~km}$ from eastern Chad to the Nile. Geomorphological and palaeontological investigations have confirmed that this wadi was still an important tributary of the Nile during the early Holocene; later it was transformed into a chain of freshwater lakes fed by local rainfall. Since the Wadi Howar was both a settlement area with ecologically favourable conditions and a route connecting the inner regions of Africa and the Nile valley, the several prehistoric sites which have been discovered confirm that it was an important site of population activity and interregional cultural contacts.

The rich archaeological and archaeozoological potential and the geomorphological and topographical variety of these sites provide detailed insight into the structures of the settlements and their strategies for survival. They also supply the necessary data for a reliable chronological and clima- tological sequence. The processes of climatic and economic change - due to desert encroachment - and their cultural implications will be examined with regards to the development and function of regional adaptation strategies as well as the large-scale role of the Wadi Howar as a connection between the Sahara and regions further south.

\section{PALAEOECOLOGY AND THE LATE HOLOCENE SETTLEMENT OF NORTHERN NAMIBIA}

Although the state of archaeological research in northernmost Namibia is not as advanced as in other parts of the country, the area has played an important role in many discussions regarding later prehistoric settlement of the whole of southern Africa. This particularly applies to the routes of the so-called "Bantu migrations" and the spread of food production and iron technology. This region, that extends from the Atlantic to the Zambesi, also provides various ecological settings for study: from desert to savannah and woodland conditions. Thus a primary aim of the project is to establish several relatively smaller study sites along a west-east transect, in order to determine how adaptation strategies and innovations varied when subject to different and changing environmental conditions.

In the first phase of the project, longterm survey activities (including test excavations) will be carried out in close cooperation with botanists and geographers. Only then - and after the archaeological potential and the state of preservation of organic matter (especially botanical remains) has been examined - can more detailed archaeological studies be designed. Although the focus of the project is environmental and economical aspects and the different modes of human adaptation, it also aims at contributing to a more reliable chronological framework for the last 3,000 years of human and environmental history in this region.

Based on a text submitted by:

\section{Stefan Kroepeln}

Coordinator, INQUA-PAGES Paleomonsoons Project Paleomonsoon Project Office

Free University of Berlin

Podbielskiallee 62

D-14195 Berlin - Germany

Phone: $+49(0) 30838-6368$

Fax (ISDN): +49(0)30 841-00363

e-mail: skroe@zedat.fu-berlin.de

\section{PEP ||}

\section{PAGES Program in Taiwan (1992-1996)}

The Past Global Changes (PAGES) program in Taiwan was initiated in March 1992 soon after the conclusion of the Asian IGBP workshop held in New Delhi, India. Since June 1992 various PAGES research projects have been funded by the National Science Council, Taipei (China). In addition, quite a few projects which are related to the PAGES have been also funded by other programs, such as LOICZ, KEEP (a JGOFS project) and the South China Sea Project. A new integrated program named Taiwan International Marine Past Global Change Study (IMAGES) has been formed and funded.

The first four years (1992-1996) were considered a promotion period for the PAGES Program, aiming to establishing research facility, expertise and protocols. A competent research team of more than 20 principal investigators has been established. Research has been conducted on a wide array of materials, ranging from historical documents, corals, tree rings, paleosols to lake and deep-sea sediments. To ensure proper analyses and further exploration of paleodata, collaboration among professional statisticians and geoscientists, in particular, has been greatly encouraged. Funding for PAGES Program has been in the range of USD $\$ 500,000$ per year, occupying $10-15 \%$ of the budget of the NSC's Geology Program. Part of the funds has also come from the NSC's Marine Science Program. While stepping into the fifth year, requests for continuing support are under a more critical peer review based upon previous accomplishments in the past four years.

The program has had a significant impact on Taiwan soft-rock geosciences. For the first time, more than a dozen geoscientists were teamed up in an integrated effort to gain a better understanding of the past environmental changes in Taiwan and its adjacent areas. A team leader was elected every two years to coordinate the interdisciplinary effort and to promote dialog and integration among the various lines of research. Forums covering various progress reports have been held seasonally by the Global Change Center, National Taiwan University. PAGES sessions have been scheduled in almost every annual Geological Society Conference and annual Ocean Science Meeting. Formal presentations of PAGES results in these and other international meetings have been an obligatory task for all the principal investigators.

The PAGES team followed the recommendations of the IGBP PAGES (IGBP Report No.6, 1988) in emphasizing two temporal streams: 1) the past 2000 years, 2) the last 150,000 years. The main endeavor in the beginning phase was to focus on the multi-proxy reconstruction of past environmental changes and data integration. Taking advantages of the availability of multiple archives in Taiwan and the adjacent areas, scientists obtained season, decade, century and millennium paleorecords from coral, tree-ring, paleosol, lake and marine sediments. Further integration and exploration of these proxy data are being undertaken.

A readjustment of the original PAGES research strategy has been made in collaboration with the new research foci as specified by the PAGES new workplan (IGBP Report N0. 28, 1994). The Taiwan area is situated in a key linking area bridging the northern and southern hemispheres in the PEP II transect. The changing conditions of the Asia monsoon, west Pacific warm pool, ENSO and marine circulation are sure to leave discernible reflections in the paleo-records of Taiwan. The PAGES team strives to reconstruct local records and to interpret the records regionally, if not globally.

To foster PAGES research in the monsoon Asia area, an international workshop was held in Taipei, Taiwan, April 21-23, 1993. The theme was: the "High Resolution Records of PastCli- 
mate from Monsoon Asia: the last 2000 Years and Beyond". The workshop was sponsored by the IGBP PAGES Program, and was financially co-sponsored by the National Science Council, Republic of China and the National Science Foundation, USA. More than 150 participants from eight countries attended the workshop. A full report of the workshop conclusions and recommendations was compiled by Raymond Bradley (USA) as a PAGES Workshop Report (Series 93-1), and a summary was published in the EOS (74:601-603). A selection of papers presented in the workshop was published in 1994 by the Terrestrial, Atmosphere and Oceanic Sciences in a special PAGES issue (TAO, vol. 5, No. 3, p.349-442).

While the team members rejoice over a number of significant accomplishments, they acknowledge that there will be a continuing struggle to ensure that Taiwan geoscientists can make further significant contributions to this global project. The initial success is only seen as the beginning of yet more promising progress in PAGES research in the areas of East Asia monsoon as well as in the crucial linkage of the subtropical area in the PEP II transect.

\section{Kuo-Yen Wei and Ping-Mei Liew}

Department of Geology, National Taiwan University

David Der-Duen Sheu and Chen-Tung arthur Chen Institute of Marine Geology and Chemistry,

National Sun-Yat-Sen University

\section{Kuo-Yen WeI}

Professor of Geology

Dept. of Geology, National Taiwan University 245

Choushan Road

Taipei, TAIWAN, ROC

Phone: 886-2-2691143

Fax: 886-2-3636095

e-mail: weiky@cc.ntu.edu.tw

\section{Documenting Past: \\ Environmental Changes in Taiwan and Adjacent Areas Results of PAGES Taiwan 1992-1996}

Compiling and analyzing high-resolution records of past environmental changes from both historical and natural archives has been a major task of PAGES (Sheu et al., 1994). Although the Taiwan PAGES Program only started in 1992, significant results have already appeared in various international and local periodicals. Some such results are summarized in this document.

\section{Millennium Records from Deep-sea Sediments}

Paleoceanographic studies (Wei et al., 1996, Huang et al., in press b, Wei et al., in press) indicate that the last glacial maximum (LGM) in the marginal seas around Taiwan was at about $14-15$ thousand years ago (ka) (in carbon-14 age), corresponding to a calibrated calendar age of 17-18 ka. During the LGM, the axis of the Kuroshio shifted slightly to the east (Chen et al., 1992). The summer sea-surface temperatures (SSTs) off the east coast of Taiwan were similar to today's at about $29^{\circ} \mathrm{C}$ through the late Quaternary, whereas the winter SSTs $\left(\sim 22.5^{\circ} \mathrm{C}\right)$ were $\sim 4^{\circ} \mathrm{C}$ lower than today during the last glacial period (Chen et al., 1992).

The South China Sea witnessed a colder winter during the LGM: the SSTs were about $18^{\circ} \mathrm{C}$, which is $\sim 6^{\circ} \mathrm{C}$ lower than today's winter SST (Wei et al., 1996). The winter monsoon was considered to have been stronger during the LGM than today (Fig. 1); consequently, ocean surface was better mixed and yielded higher biological productivity (Wei et al., 1996, Huang et al., in press b, Wei et al., in press). A higher terrigenous flux during the LGM, together with higher sea-surface productivity, resulted in higher sedimentation rates and a larger accumulation of organic carbon and carbonates during the LGM. A carbonate preservation spike occurred at $\sim 12$ $\mathrm{ka}$, synchronous with the global preservation event of the Termination I (Wei et al., 1996, Chen et al., in press). A 1.05 million-year record of paleoceanographic changes in the southern South China Sea was reported by Chen et al (submitted).

\section{Century to Decade Records from Lake Sediments}

The interlaminated dark and light-colored lake sediments obtained from several mountain lakes appear to reflect large-scale wet and dry cycles over the past 2,400 years (Chen et al., 1993; Lou et al, 1996). The detected 450years periodicity is similar to that of the solar oscillation (Chen et al., 1993). The Medieval Warm Period (1000-1300 AD) and the Little Ice Age (1300-1850 AD) were recognized (Lou et al., 1996). These two epochs were also identified from palynological records of the Central Range (Liew et al., 1995). Pollen data in Taiwan imply the occurrence of a mid-Holocene climatic optimum during $7-3.7 \mathrm{ka}$ and a cooling period during 3.7 - $2 \mathrm{ka}$ (Liew et al., 1995). A drastic floral change took place at about 4.8 ka (Liew and Huang, 1994).

Palynological data indicated that the vegetation distribution displaced vertically by about $800 \mathrm{~m}$ between the last glacial and the Holocene, implying a $4.8^{\circ} \mathrm{C}$ change in temperature in the western foothill region of central Taiwan (Huang et al, in press a). It is inferred that in east Asia, during the LGM (21 $15.8 \mathrm{ka}$ ), the forest in the uplands became half open, while most of the lowlands were occupied by grassland. Less humid conditions than today prevailed in Taiwan during the LGM (Liew et al., submitted).

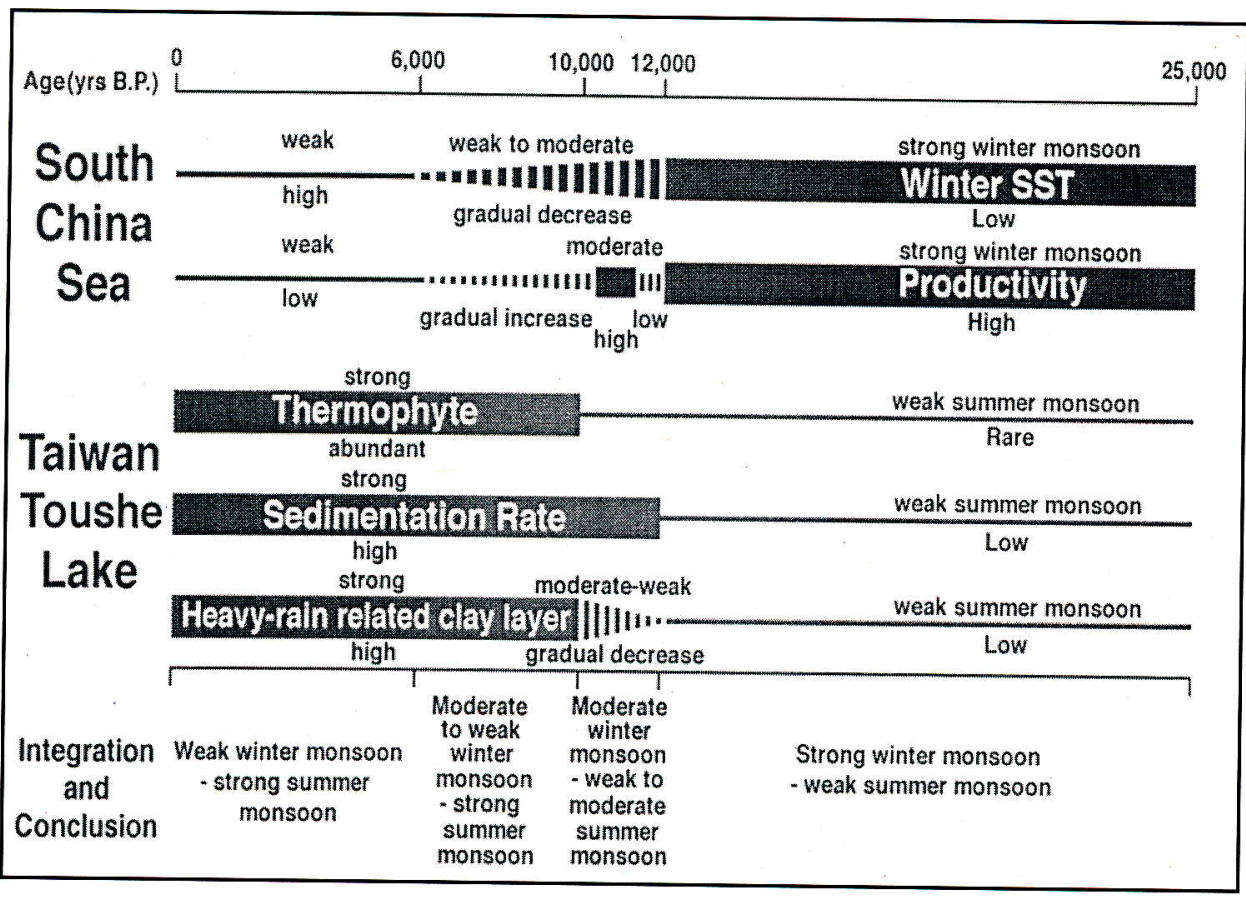

Fig. 1: An integrated monsoon history inferred from the proxy records in South China Sea and central Taiwan lake cores for the last 25,000 years. The marine and lake records are complementary and consistent, suggesting that the East Asian monsoon system has evolved from an strengthened winter monsoon during the last glaciation through a moderate to weak winter and summer monsoons during the deglaciation to an enhanced summer monsoon in the Holocene. (from Huang et al., in press a). 


\section{Annual to Seasonal Records from Tree-Rings}

Studies of tree rings of Taiwan fir allowed for the reconstruction of the summer and winter temperatures of the alpine mountain area over the past 300 years (Fig. 1). It was thereby demonstrated that cold climate prevailed during the Little Ice Age (Tsou and Liu, in press). Further more, carbon isotopic variations in a 120 -year-old Taiwan fir responded negatively to the mean May-October temperatures after stable growth with a coefficient of $-0.46 \%{ }^{\circ} \mathrm{C}^{-1}$ (Sheu et al, 1996).

\section{Monthly Records from Corals}

An empirical relationship between the [Sr/Ca] concentration ratio in corals vs. seasurface-temperature (SST) has been established in southern Taiwan. The temporal resolution is better than a month, while the SST can be reconstructed with an error less than $0.1^{\circ} \mathrm{C}$ (Lee et al., 1995; Shen et al., in press). Applying this paleo-thermometry, Lee et al (1995) detected a $1-2^{\circ} \mathrm{C}$ warming for the winter 19821983, corresponding to the strong ENSO of 1982. The calibration effort will soon be ex- tended to a time span of greater than 100 years, covering the entire period since the first introduction of modern meteorological instruments to Taiwan.

\section{Synopsis}

Deep-sea sedimentary records of the South China Sea suggest that the winter monsoons were strengthened during the last glacial (25-12 ka) while the summer monsoons were weaker than today's (Fig. 1). Ever since $12 \mathrm{ka}$, the winter monsoons have weakened, while the strength of the summer monsoons have gradually increased. An abrupt Younger Dryas-like cooling event occurred from 11.3 to $10.3 \mathrm{ka}$ radiocarbon years BP (Huang et al, in press a). Palynological data obtained from central Taiwan show consistent and complementary evidence of this although the Younger Dryas is not recognizable. The vertical shifting of vegetation in the deglaciation period suggests a warming of about $5^{\circ} \mathrm{C}$ in the subalpine area of central Taiwan. Pollen data in Taiwan imply the occurrence of a mid-Holocene climatic optimum during 7-3.7 ka and a cooling period during $3.7-2 \mathrm{ka}$. Over the past 2000 years, the climate has become warmer and wetter, intervened with the conspicuous Medieval Warm Period (1000-1300 AD) and the Little Ice Age (1300-1850 AD). Tree-ring data have also confirmed the effect of the Little Ice Age in the Taiwan alpine mountain region. The fluctuation of humidity over the past 2400 years as derived from lake sediments suggests that the recognized dry/cold periods have coincided with major historical disturbance events in Chinese history. The precise calibration of coral thermometry based upon the [Sr/ $\mathrm{Ca}$ ratio has been successful, it now appears promising that an accurate reconstruction of sea-surface temperature for the past several thousand years can be made.

\section{Kuo-Yen Wei and Ping-Mei Liew}

Department of Geology, National Taiwan University

David Der-Duen Sheu and Chen-Tung Arthur Chen Institute of Marine Geology and Chemistry,

National Sun-Yat-Sen University

For full references, please contact:

Kuo-Yen Wei

Professor of Geology

Dept. of Geology, National Taiwan University 245

Choushan Road

Taipei, TAIWAN, ROC

Phone: 886-2-2691143

Fax: 886-2-3636095

e-mail: weiky@cc.ntu.edu.tw

\section{PAGES CALENDAR}

(* Open meetings. All interested scientists are invited to attend)

*April 4 - 8, 1997, Lammi, Finland - 'Circum Arctic Paleoenvironments'(CAPE) Synthesis Workshop: "Holocene Spatial and Temporal patterns of environmental change in the Arctic" Contact: S. Hicks, Fax: (358) 8553 1484; e-mail: sheila.hicks@oulu.fi

*April 14 - 18, 1997, IAEA Vienna, Austria - International Symposium on 'Isotope Techniques in the Study of Past and Current Environmental Changes in the Hydrosphere and the Atmosphere' Contact: Ms. T. Niedermayr, Conference Service Section - e-mail: niederma@adpol.iaea.or.at

*April 21 - 25, 1997, Vienna, Austria - European Geophysical Society - See especially Session $\mathrm{OA} 13$, "Climate variability observation and modelling", sub-session "Reconstruction of past climates through Modelling and Observations"

Contact: G. Ramstein, e-mail: ramstin@asterix.saclay.cea.fr

*May 10 - 15, 1997, Castelvecchio Pascoli, Italy - Paleoclimate modelling and analysis, Quaternary paleoclimate analysis

Contact: Josip Hendekovic, ESF, Phone: +33 38876 7135; Fax: +3388 36 6987; e-mail: euresco@esf.org

July 6 -11, 1997, Hobart, Australia - SCAR/GLOCHANT AND IGBP/PAGES Worshop on the "late quaternary sedimentary record of the antarctic ice margin evolution" (ANTIME)

Contact: Ian Goodwin, Phone: +61 36226 7544, Fax: +61 3 6227 7650; e-mail: ian.goodwin@antcrc.utas.edu.au

*August 24 - 30, 1997, Krasnoyarsk, Russia - Siberian Transect Workshop on "Spatial-temporal dimensions of High-Latitude Ecosystem Changes"

Contact: V.A. Koptyug, Fax: (7) 383235 4846; e-mail: evag@ifor.krasnoyarsk.su

*August 28 - September 2, 1997, Heiligkreutz/Riedlingen, Germany - "Seventh International Symposium on Palaeolimnology"

Contact: J. Merkt, Fax (49) 511643 3667; e-mail: merkł@gatel .bgr.d400.de.

This Symposium is followed by a scientific celebration of the 80 th birthday of Herbert E. Wright, Jr. at Wengen, Switzerland (Sept. 8 - 11)

Contact: B. Ammann, Fax: (41) 313322059

September 7 - 13, 1997, Johannesburg, South Africa - Third Symposium of African Palynology Contact: Ann Cadman, University of Witwatersrand, e-mail: 106caa@cosmos.ac.za

*April 19 - 23, 1998, UK - "PAGES Open Science Meeting", Royal Holloway University of London, UK Contact: Frank Oldfield, PAGES CPO Switzerland, Fax: +4131312 3168; e-mail: oldfield@pageigbp.unibe.ch

*May 16 - 23, 1998, Torshavn, Faroe Islands - "Environmental Change in Atlantic Islands"

Contact: C. Caseldine, University of Exeter, UK - Phone: +44 1392263 347; Fax: +44 1392263 342; e-mail: c.j.caseldine@exeter.ac.uk

*August 3 - 11, 1999, Durban, South Africa - "The Environmental Background to Hominid Evolution in Africa", INQUA XV International Congress, International Congress Centre Durban

Contact: Margaret Avery, Phone: +27 21243 330; Fax: +27 21246716 ; e-mail: mavery@samuseum.ac.za 


\title{
Great Barrier Reef 'Climatic Optimum' at 5,800 y BP
}

\author{
M.K. Gagan, L.K. Ayliffe, S. Anker, D. Hopley, M.T. McCulloch, P.J. Isdale, J.M.A. Chappell and J. Head
}

Parts of North America and Europe were warmer during the mid Holocene while a stronger monsoon produced warmer/wetter climates in northern Africa and central Asia (COHMAP, 1988). The nature of the mid Holocene 'climatic optimum' is less clear for the southern hemisphere; although recent work on ice cores from high-altitude tropical glaciers in Peru indicates that air temperatures were warmer from 8,000 to 5,000 Y BP (Thompson et al., 1995). At the same time, sea surface temperatures (SSTs) along the coast of Peru may have been warmer and less variable suggesting that the El Niño - Southern Oscillation (ENSO) may have been weak, or absent (Sandweiss et al.,1996).

The new PAGES-CLIVAR initiative on Annual Records of Tropical Systems (ARTS) promotes the synthesis of paleoclimatic, instrumental, and modeling data to improve our understanding of tropical climate variability. An important goal of the ARTS initiative is to reconstruct climate systems during ancient periods with different background climates and forcings.

Toward this goal, we have applied a multi-tracer approach to a fossil coral from the windward side of Orpheus Island, central Great Barrier Reef, to reconstruct climatic conditions in northeast Australia during one century of the mid Holocene (Gagan et al., 1995). At Orpheus, well-preserved massive Porites micro-atolls have been cored to reveal 100 years of continuous coral growth. The largest colony, for which preliminary data are presented, has a conventional radiocarbon age of 5,800 Y BP. The fossil coral data presented here have been calibrated via proxy data for modern corals growing adjacent to the fossil coral colony.

Examination of the coral UV fluorescence, indicating the intensity of runoff from mainland rivers (Isdale, 1984), suggests that monsoonal rainfall during this century of the mid Holocene was much less variable than today (see Figure). The intensity of UV fluorescence for modern corals analogues varies from 0 to 700 fluorescence units in response to cycles of drought and flood. In contrast, fluorescence in the mid Holocene coral is restricted to 100 to 300 units. The results indicate that droughts and floods were rare during this century of the mid Holocene.

In order to further verify the UV fluorescence record, we made high resolution measurements of the coral Sr/Ca to examine SSTs (Beck et al., 1992) and $\delta^{18} \mathrm{O}$ to document the seasonal dynamics of monsoonal rainfall (Gagan et al., 1994; McCulloch et al., 1994). The calibrated coral Sr/Ca-SSTs for years 80 to 96 indicate that mid Holocene SSTs were $1^{\circ} \mathrm{C}$ warmer than those of the last two decades. If these elevated SSTs represent regional warming in the western Pa- cific, higher evaporation rates and persistent summer cloudiness should follow. Note that the summer SSTs are closely confined to a mean temperature of about $29.5^{\circ} \mathrm{C}$, and rarely exceed $30^{\circ} \mathrm{C}$. This is the situation today further north near New Guinea where high evaporation rates produce persistent summer clouds which block incoming short-wave radiation, resulting in a negative feedback on further increases in SST. Persistent clouds also tend to damp fluctuations in summer SSTs. The warm, consistent summer SSTs indicated by the coral $\mathrm{Sr} / \mathrm{Ca}$ reinforce the UV fluorescence in suggesting that summers in the Great Barrier Reef were typically cloudy with moderate monsoonal rainfall.

The 16 -year $\mathrm{Sr} / \mathrm{Ca}-\delta^{18} \mathrm{O}$ record also provides a rare opportunity to look for evidence of individual ENSO events. Contemporary ENSO-induced droughts in northeast Australia coincide with cool winter SST anomalies of at least $1-2^{\circ} \mathrm{C}$. In addition to providing information about SST, coupled measurements of coral Sr/Ca and $\delta^{18} \mathrm{O}$ make it possible to determine seawater $\delta^{18} \mathrm{O}$ by removal of the temperature component of the coral $\delta^{18} \mathrm{O}$ signal. Seasonal changes in seawater $\delta^{18} \mathrm{O}$, as registered by the coral, provide a good measure of the magnitude of river runoff and precipitation. The coral record spans the three years that we perceived to be the driest in 100 years, based on vsual inspection of the coral UV fluorescent bands (years 82-85 in lower panel). Despite this period being fairly dry, the winter cooling associated with this 'drought' is negligible, and certainly not indicative of ENSO. This record is admittedly short, but the $\mathrm{Sr} /$ $\mathrm{Ca}$ and $8^{18} \mathrm{O}$ data have now been extended to nearly 30 years with no sign of winter cooling or drought indicative of ENSO.

Taken together, the evidence suggests that this century of the mid Holocene was marked by warmer SSTs, more dependable monsoonal rainfall, and possibly a weaker ENSO. The persistence in time of the apparent weakening of the mid Holocene ENSO is unknown but, if real, the ramifications of a weakened ENSO should be evident in high-resolution palaeoclimate records throughout much of the tropics.

\section{Text submitted by:}

\section{Dr. Michael K. Gagan}

Environmental Geochemistry Group

Research School of Earth Sciences

Australian National University

Canberra, A.C.T. 0200, Australia

Phone: +6162495926

E-mail: michael.gagan@anu.edu.au

\section{References:}

Beck, J.W., R.L. Edwards, E. Ito, F.W. Taylor, J. Recy, F. Rougerie, P. Joannot and C. Henin 1992. Sea-surface temperature from coral skeletal stronfium/calcium ratios. Science 257: 644-647.

COHMAP Members, 1988. Climatic changes of the last 18,000 years: observations and model simulations. Science 241: 1043-1052.

Gagan, M.K., A.R. Chivas and P.J. Isdale 1994. High resolution isotopic records from corals using ocean temperature and mass-spawning chronometers. Earth Planet. Sci. Lett. 121: 549-558.

Gagan, M.K., L.K. Ayliffe, M.T. McCulloch, S. Anker, D. Hopley and P.J. Isdale 1995. Sr/Ca and $\delta^{18} \mathrm{O}$ in Great Barrier Reef corals and ENSO dynamics at $5.8 \mathrm{ka}$ BP. American Geophysical Union Fall Meeting, EOS Supplementary Issue 76: 316.

Isdale, P. 1984. Fluorescent bands in massive corals record centuries of coastal rainfall: Nature 310:578-579.

McCulloch, M.T., M.K. Gagan, G.E. Mortimer, A.R. Chivas and P.J. Isdale 1994. A high-resolution Sr/Ca and $\delta^{18} \mathrm{O}$ coral record from the Great Barier Reef, Australia, and the 1982-1983 El Niño. Geochim. Cosmochim. Acta 58: 2747-2754.

Sandweiss, D.H., J.B. Richardson III, E.J. Reitz, H.B. Rollins and K.A. Maasch, 1996. Geoarcheological evidence from Peru for a 5,000 years BP onset of El Niño. Science 273: 1531-1533.

Thompson, L.G., E. Mosley-Thompson, M.E. Davis, P.N. Lin, K.A. Henderson, J. Cole-Dai, J.F. Bolzan and K.B. Liu, 1995. Late glacial stage and Holocene tropical ice core records from Huascaran, Peru. Science 269: 46-50. 


\section{GREAT BARRIER REEF SSTS AND RUNOFF AT 5,800 y BP}
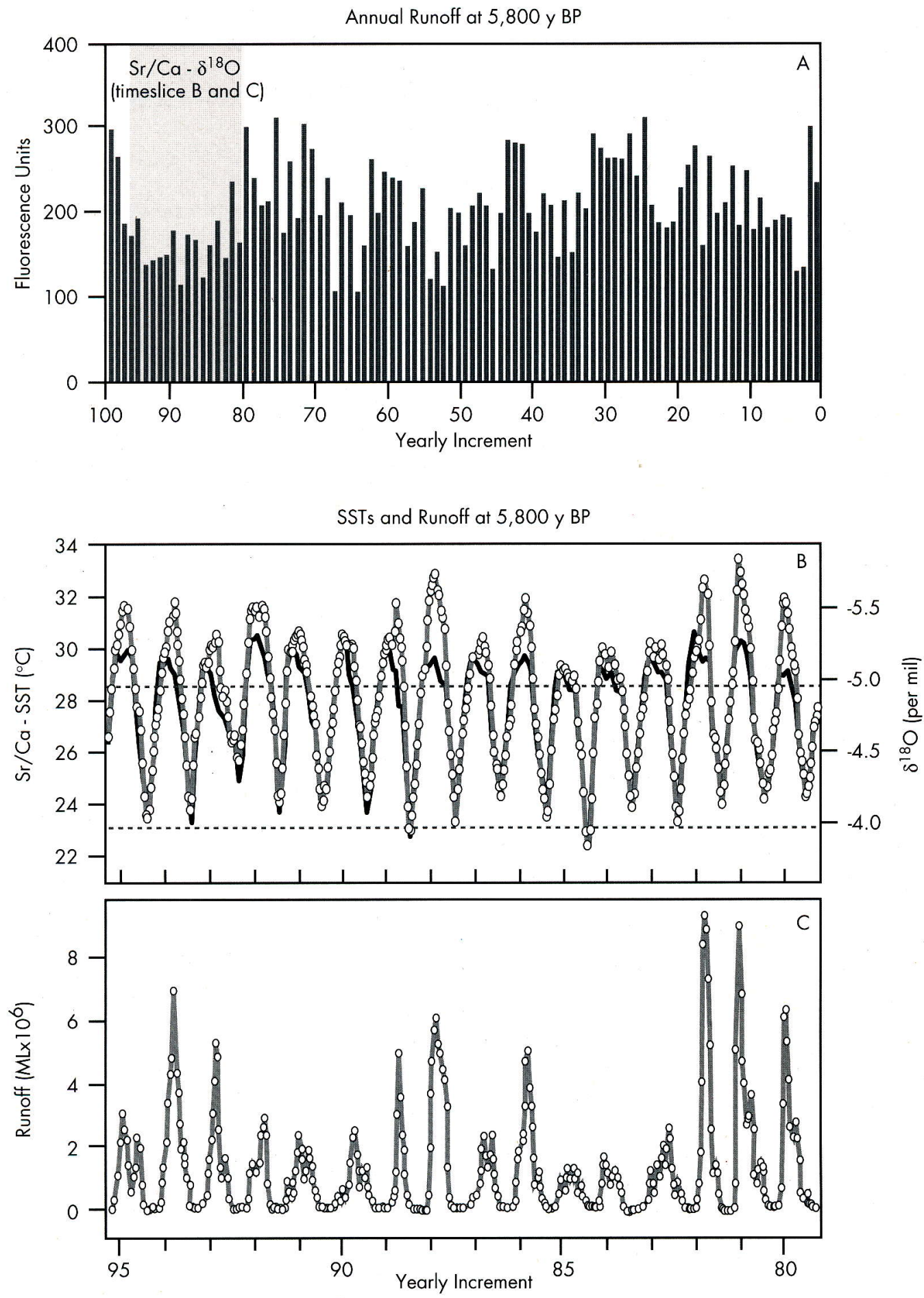

A) 100-year record of annual UV fluorescence for the 5,800 y BP Porites micro-atoll from Orpheus Island, central Great Barrier Reef.

Bar labelled ' $\mathrm{Sr} / \mathrm{Ca}-18 \mathrm{O}^{\prime}$ indicates 16-year interval chosen for coupled $\mathrm{Sr} / \mathrm{Ca}$ and $\delta^{18} \mathrm{O}$ measurements.

B) 16-year record of coral $\mathrm{Sr} / \mathrm{Ca}$ (black line) and $\delta^{18} \mathrm{O}$ values (grey line with dots) converted to SST.

The difference between the $S r / C a$ and $\delta^{18} O$ curves represents the intensity of monsoonal runoff.

Horizontal lines show the mean winter and summer SSTs for 1970-1994.

C) Coral $\delta^{18} O$ residuals converted to show the magnitude of runoff from the palaeo-Burdekin River. 